Canadian

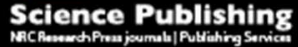

Canadian Journal of Earth Sciences Revue canadienne des sciences de la Terre

\title{
Isotopic evidence for a lithospheric origin of alkaline rocks and carbonatites: an example from southern Africa
}

\begin{tabular}{|r|l|}
\hline Journal: & Canadian Journal of Earth Sciences \\
\hline Manuscript ID & cjes-2015-0145.R1 \\
\hline Date Submitted by the Author: & 26-Feb-2016 \\
\hline Complete List of Authors: & $\begin{array}{l}\text { Ashwal, Lewis; School of Geosciences } \\
\text { Patzelt, Madelein; University of the Witwatersrand, School of Geosciences; } \\
\text { Harz-Metall GmbH } \\
\text { Schmitz, Mark; Boise State University, Department of Geosciences } \\
\text { Burke, Kevin; University of Houston, Department of Geosciences }\end{array}$ \\
\hline Keyword: & $\begin{array}{l}\text { carbonatite, nepheline syenite, lithosphere, radiogenic isotopes, mantle } \\
\text { source }\end{array}$ \\
\hline & \\
\hline
\end{tabular}

SCHOLARONE ${ }^{\mathrm{m}}$

Manuscripts 
1 Isotopic evidence for a lithospheric origin of alkaline rocks 
${ }^{2}$ Harz-Metall GmbH

Hüttenstraße 6

38642 Goslar

Germany

madelein.patzelt@recylex.de

${ }^{3}$ Department of Geosciences

Boise State University

Boise, ID 83725-1535

markschmitz@boisestate.edu

${ }^{4}$ Department of Geosciences

Houston, TX 77204-5007 
Cambridge, MA 02139

40

USA

41

kburke1@mit.edu

42

43

44

45

46

47

48

49

50

51

52

53

Corresponding author:

Prof. Lewis. D. Ashwal

School of Geosciences

University of the Witwatersrand

Private Bag 3

WITS 2050

South Africa

lewis.ashwal@wits.ac.za

Phone: +27-22-717-6652

Fax: +27-22-717-6579 
55 Abstract: Alkaline rocks and carbonatites, including nepheline syenites, are well

56 established as mantle-derived magmatic products, but the nature and location of their

57 mantle sources is debated. Some workers have used isotopic compositions to infer mixed

58 mantle plume type sources such as EM1, HIMU and FOZO, implying derivation from the

59 subcontinental asthenosphere. Other models favour an entirely lithospheric source,

60 whereby the magmas, originally formed during intracontinental rifting, became deformed

61 and subducted into the mantle lithosphere during later continental collisions, and

62 constituted part of a source component for later rift-related alkaline and carbonatite

63 magmatism. We tested this model using $\mathrm{Sr}, \mathrm{Nd}$ and $\mathrm{Hf}$ isotopic compositions of

64 deformed and undeformed nepheline syenites and carbonatites from 3 occurrences in

65 southern Africa, representing emplacement over a 1 Ga time span. These include: Bull's

66 Run, South Africa (1134 Ma), Tambani, Malawi (726 Ma) and the Chilwa Alkaline

67 Province, Malawi (130 Ma). Mixing modelling indicates that the isotopic compositions of

68 the early Cretaceous Chilwa samples can be accounted for if their source consisted of a

69 blend of $\sim 99 \%$ depleted subcontinental mantle lithosphere (DM) and $\sim 0.5-1 \%$ of a

70 subducted component similar to the Neoproterozoic Bull's Run nepheline syenites. We

71 do not consider the Bull's Run material specifically as the component involved in the

72 Chilwa source, but our model illustrates an example of how recycled, older, alkaline

73 magmatic rocks can contribute to the mantle sources of younger alkaline rock and

74 carbonatite magmatism. This model accounts for the observation of recurrent alkaline

75 rock and carbonatite magmatism over hundreds of m.y. in spatially restricted areas like 
76 southern Africa. Carbonatite and related alkaline magmatic rocks, therefore, need not

77 owe their origin to deep, sublithospheric melting processes.

81 Keywords:

82 Carbonatite

83 Nepheline syenite

84 Lithosphere

85 Radiogenic isotopes 


\section{Introduction}

Isotope geochemistry shows that young $(<200 \mathrm{Ma})$ alkaline rocks and carbonatites

89 (acronym: ARCs), including nepheline syenites, syenites and nephelinites, are mantle-

90 derived. Evidence includes the variable, but generally low initial Sr ratios (0.703-0.705),

91 positive initial $\varepsilon_{\mathrm{Nd}}$ values (to +7 ), $\delta^{18} \mathrm{O}$ values mainly between 6 and $9 \%$, and $\mathrm{Pb}$

92 isotopic compositions consistent with known or inferred mantle sources (e.g. Bell and

93 Blenkinsop 1989; Nelson et al. 1988; Kwon et al. 1989, Deines 1989; Sasada et al. 1997).

94 Because of their very high concentrations of $\mathrm{Sr}, \mathrm{Nd}$ (and to a lesser extent, $\mathrm{Pb}$ ),

95 carbonatites and related rocks can be used as mantle probes throughout geologic time,

96 unhindered by the effects of crustal contamination and in-situ decay of parent isotopes

97 (Bell et al. 1982; Bell and Blenkinsop 1987a, 1989).

100 systematics (Bell et al. 1982; Bell and Blenkinsop 1987a), implied derivation from a

101 long-lived, depleted source with $\mathrm{Rb} / \mathrm{Sr}=0.017 \pm 0.002$ and $\mathrm{Sm} / \mathrm{Nd}=0.358 \pm 0.008$ that

102 was interpreted to represent sub-continental lithospheric mantle. Later work, mainly on

103 young ARCs from East Africa, revealed that their initial $\mathrm{Sr}$ and $\mathrm{Nd}$ isotopic compositions

104 are negatively correlated and fall on a so-called East African Carbonatite Line (EACL),

105 implying the involvement of two mantle sources, one depleted, and one enriched relative

106 to bulk Earth and CHUR (Bell and Blenkinsop 1987b; Bell and Tilton, 2001). This

107 initiated debate as to whether the ARC sources were situated in the lithospheric or

108 asthenospheric mantle, or both (e.g., Bell and Blenkinsop 1989), and through the addition 
109 of $\mathrm{Pb}$ and $\mathrm{Hf}$ isotopic measurements (e.g. Kwon et al. 1989; Bizzarro et al. 2002), the

110 number of mantle sources under consideration increased to include DMM, EM1, HIMU

111 and FOZO (Bell and Tilton 2002). Some now argue for the dominance of just two

112 asthenospheric sources (EM1 and HIMU) (Bizimis et al. 2003; Bell and Simonetti 2010).

The association of ARCs with intracontinental rift zones is well established (e.g.

115 Bailey 1974, 1977, 1992), and a prominent example is the East African Rift, where a

116 large fraction of the world's carbonatite and associated alkaline plutonic and volcanic

117 rock occurs (Woolley 2001). Bailey $(1974,1977,1992)$ also drew attention to the

118 repeated emplacement over 100s of millions of years of ARC materials within spatially

119 restricted regions, an observation that we address in this paper. In addition, ARCs have

120 been credibly connected to deep mantle plumes (e.g. Bell 2001), a suggestion that is

121 borne out by rare examples of carbonatites in ocean islands such as Cape Verde, the

122 Canary Islands, and Hawaii (Gerlach 1988; Hoernle et al. 2002; Dixon et al. 2008).

124 Burke et al. (2003) proposed a Wilson cycle model in which ARCs intruded

125 during intracontinental rifting become deformed (acronym: DARCs) during later

126 continental (or oceanic arc - continent) collisions. They suggested that DARC material

127 subducted prior to and during collision to depths of $100-150 \mathrm{~km}$, became part of the

128 mantle lithosphere, and could thereby represent a source component for later rift-related

129 ARC magmatism. This model would account for Bailey's observation of recurrent ARC

130 magmatism over hundreds of m.y. in reactivated rifts and rifts developed over suture 
131 zones, such as has characterized southern Malawi (Fig. 1). It also implies an entirely

132 lithospheric source for ARC magmatism.

133

134 In this paper we test the hypothesis of Burke et al. (2003) using Sr, Nd and Hf

135 isotopic data for three occurrences of ARCs and DARCs emplaced in southern Africa

136 over a time span of 1 b.y., from the Neoproterozoic to the Late Cretaceous. Our results

137 suggest that a combination of lithospheric mantle sources is a viable possibility for the

138 origin of at least some ARCs.

141 Geology and Sampling

143 The locations of deformed and undeformed alkaline rocks and carbonatites in

144 Africa, based on the compilation of Woolley (2001), are shown in Fig. 1. Age

145 information is not available for many of these occurrences, although many of the

146 undeformed examples are Mesozoic or younger, and are associated with Jurassic to

147 Cretaceous $(\sim 184-132 \mathrm{Ma})$ and Cenozoic $(\sim 34-0 \mathrm{Ma})$ magmatic activity of the East

148 African rift system (Burke et al. 2003). Undeformed occurrences as old as $\sim 2$ Ga include

149 the Phalaborwa and Schiel carbonatites of South Africa (Eriksson 1989; Walraven et al.

150 1992) and the Hassi-El-Fogra nepheline syenite of Mauritania (Lameyre and Lasserre

151 1967). Deformed occurrences are mainly Pan-African in age (500-750 Ma), although the

152 nepheline syenite gneisses at Nhonglong, Cameroon may be as old as $2890 \mathrm{Ma}$ (Lasserre 
153 and Soba 1976); the deformed carbonatites of In'ouzzal, Algeria are 2 Ga (Bernard-

154 Griffiths et al. 1988).

In this paper, we report new $\mathrm{Sr}, \mathrm{Nd}$ and $\mathrm{Hf}$ isotopic data for three occurrences in

157 southern Africa (Fig. 1), ranging in age from Neoproterozoic (Bull's Run DARC, South

158 Africa) to Pan-African (Tambani DARC, Malawi) to Late Cretaceous (Chilwa Alkaline

159 Province ARCs, Malawi). Brief descriptions of the geological settings of these

160 occurrences are given below.

161

162 Bull's Run, South Africa. In the Natal part of the 1000-1100 Ma Namaqua-Natal

163 Metamorphic Belt (NNMB), a variety of alkalic gneisses referred to as the Bull's Run

164 Complex occurs in an elongate sliver $\sim 15 \mathrm{~km}$ long and up to $2 \mathrm{~km}$ wide (Charlesworth

165 1981; Scogings and Forster 1989). The Complex forms part of a set of thrust-bounded

166 slices in the Tugela terrane (Johnston et al. 2003), just south of the south-dipping Natal

167 Thrust Front, which juxtaposes rocks of the NNMB against the Archaean Kaapvaal

168 Craton (Fig. 2). Metamorphic grade is upper amphibolite. The Complex consists of an

169 inner zone of nepheline-bearing biotite syenite gneisses of variable grain size, some of

170 which contain abundant scapolite. These rocks are enveloped by nepheline-free biotite-

171 muscovite syenitic gneisses. Three small bodies (largest $=100 \times 20 \mathrm{~m})$ of deformed

172 carbonatite occur at the eastern margin of the Complex, within the biotite-muscovite

173 syenite gneiss. The carbonatites are dominated by calcite, with lesser microcline, albite,

174 apatite and biotite, and accessory ilmenite, pyrite and pyrochlore. Some of the syenitic

175 gneisses contain mm- to cm-sized zircon crystals, one of which yielded U-Th-Pb ages of 
$1761140 \pm 35 \mathrm{Ma}$ and $1100 \pm 40 \mathrm{Ma}$; these are some of the first $\mathrm{U}-\mathrm{Pb}$ zircon ages measured

177 in southern Africa (Nicolaysen and Burger 1965). These authors also determined an

178 imprecise $\mathrm{Rb}-\mathrm{Sr}$ age of $900 \mathrm{Ma}$ from biotite taken from a syenitic gneiss.

179

180 Tambani, Malawi. In the Tambani-Salambidwe region of southwestern Malawi

181 there is an elongate mass of nepheline syenite gneiss $\sim 75 \mathrm{~km}^{2}$ in areal extent referred to

182 as the Tambani body (Fig. 3, Cooper and Bloomfield 1961; Ashwal et al. 2007). The

183 nepheline-bearing gneisses were described as typically "migmatitic", composed of

184 alternating bands of varying colour index on a cm-scale. Coarser bands of pegmatitic

185 material contain nepheline crystals up to $7 \mathrm{~cm}$ across. Contacts of the Tambani body are

186 conformable with the country rocks, which include dominantly biotite- and/or

187 hornblende-bearing paragneisses and quartz-muscovite schists. To the north of the

188 Tambani body the country rocks are dominated by hornblende-clinopyroxene-plagioclase

189 gneisses, which may represent metavolcanics or metabasic intrusives (Cooper and

190 Bloomfield 1961). Metamorphic grade in the Tambani body and the immediately

191 surrounding country rocks appears to have reached amphibolite facies. Mineralogically,

192 the Tambani rocks consist of varying proportions of microcline microperthite,

193 plagioclase, nepheline, biotite, muscovite, and zircon, with or without corundum, apatite

194 and magnetite

195

196 Some of the Tambani nepheline syenite gneisses contain euhedral zircon crystals

197 up to $5 \mathrm{~cm}$ across (Ashwal et al. 2007). Near our sampling locality (Fig. 3) an

198 entrepreneurial venture has been set up whereby the villagers are actively collecting and 
199 stockpiling zircon crystals that have weathered out into the local fields; some 60 tons of

200 zircon have been amassed. Some of these zircons are amongst those used for age

201 determinations by $\mathrm{Pb}-\alpha$ methods (Cooper and Bloomfield 1961), which yielded a range

202 of results between 515 and 659 Ma. More recent results using TIMS and SHRIMP

203 methods give an age of $726 \pm 6 \mathrm{Ma}$, interpreted as representing the time of magmatic

204 crystallization of the nepheline syenites (Ashwal et al. 2007). The age of amphibolite

205 facies metamorphism was constrained at $522 \pm 17$ Ma by TIMS analysis of monazite

206 (Ashwal et al. 2007).

207

208 The Tambani nepheline syenite gneisses represent a good example of repeated

209 alkaline and carbonatitic magmatism occurring over long periods of geological time in a

210 spatially restricted area. Just over $15 \mathrm{~km} \mathrm{SW}$ of the Tambani body lies the Salambidwe

211 intrusion, a circular ring complex of phonolitic trachytes, agglomerates, pulaskites and

212 assorted alkaline syenites (Fig. 3, Garson 1965). The Salambidwe intrusion crosscuts and

213 domes Karoo sediments (Permian to Jurassic in age). A dense, radial swarm of

214 sölvsbergite (aegirine syenite) dykes emanates from the complex, crosscutting normal

215 faults that separate the Karoo sedimentary sequence from Precambrian basement to the

216 NE (Fig. 3). These dykes establish the proximity of the post-Triassic Salambidwe

217 intrusion to the latest Neoproterozoic Tambani body.

218

219 Chilwa Alkaline Province, Malawi In southern Malawi and adjacent

220 Mozambique there is a series of Late Cretaceous alkaline and carbonatitic intrusive and

221 extrusive rocks exposed over about $64,000 \mathrm{~km}^{2}$ that is referred to as the Chilwa Alkaline 
222 Province (Garson 1966; Woolley 1991). This Province lies at the southern end of the East

223 African Rift system, and includes the first carbonatites to be recognized in Africa

224 (Woolley 2001). The most extensive occurrences of syenite and nepheline syenite occur

225 to the west of Lake Chilwa as a series of coalescent annular plutons oriented E-W over

226 about $40 \mathrm{~km}$ (Fig. 4). These bodies were emplaced into Precambrian gneisses, which

227 have been variably fenitized near their intrusive margins. The principal intrusions include

228 the nepheline syenite - syenite plutons at Chinduzi, Mongolowe, Chaone and Chikala,

229 and the granite - syenite plutons at Zomba-Malosa (Fig. 4). The dominant rock types

230 include pulaskite $(5-10 \%$ nepheline $+1-50 \%$ mafic minerals $)$, foyaite $(5-15 \%$ nepheline \pm

231 sodalite) and perthosite (mainly microperthite \pm quartz, with mafic minerals). The mafic

232 minerals include alkalic amphiboles, aegirine and/or biotite. About $20 \mathrm{~km}$ southeast of

233 the Chikala pluton, there is a $\sim 4 \mathrm{~km}$ diameter body of carbonatitic rocks on Chilwa

234 Island, in the southwestern part of Lake Chilwa (Garson and Smith 1958) (Fig. 4). The

235 main rock types in that body include sövite (calcite-dominant carbonatite), ankeritic

236 sövite and sideritic carbonatite; the surrounding Precambrian basement rocks have been

237 extensively fenitized (Woolley 1969). Based on a variety of $\mathrm{K}-\mathrm{Ar}, \mathrm{U}-\mathrm{Pb}$ and fission track

238 ages (summarized in Woolley 2001) the nepheline syenites and carbonatites were

239 emplaced at about $130 \mathrm{Ma}$; the granite-syenite plutons at Zomba-Malosa appear to be

240 somewhat younger, at $115 \mathrm{Ma}$. Our sample suite consists of pulaskites and foyaites

241 from the Mongolowe pluton and a variety of carbonatitic rocks from Chilwa Island.

244 Analytical Methods 
246 Whole-rock samples were crushed using a steel jaw crusher and ring mill, and

247 were pulverized with an agate mortar and pestle at the Hugh Allsopp Lab (HAL),

248 University of the Witwatersrand. Major and selected trace element concentrations were

249 determined by XRF at the School of Geosciences, University of the Witwatersrand, using

250 standard techniques (Norrish and Hutton 1969; Feather and Willis 1976). Rb-Sr, Sm-Nd

251 and Lu-Hf isotopic and concentration measurements were carried about at the Carnegie

252 Institution of Washington, Department of Terrestrial Magnetism.

253

254 For $\mathrm{Rb}-\mathrm{Sr}$ isotopic analyses, $100 \mathrm{mg}$ of powders were dissolved with $5 \mathrm{ml} 29 \mathrm{M}$

$255 \mathrm{HF}+15 \mathrm{M} \mathrm{HNO}_{3}(3: 2)$ in Parr pressure vessels at $200^{\circ} \mathrm{C}$ for 72 hours, dried and re-

256 dissolved in $5 \mathrm{ml} 6 \mathrm{M} \mathrm{HCl}$ at $120^{\circ} \mathrm{C}$ for 48 hours. A $10 \%$ aliquot of the solution was

257 spiked with ${ }^{87} \mathrm{Rb}$ and ${ }^{84} \mathrm{Sr}$ tracers, fluxed overnight, dried and re-dissolved in $5 \mathrm{ml} 1 \mathrm{M}$

$258 \mathrm{HCl}+0.1 \mathrm{M} \mathrm{HF}$ at $120^{\circ} \mathrm{C}$ overnight. $\mathrm{Rb}$ and $\mathrm{Sr}$ were separated by standard cation

259 exchange chemistry (elution in $2.5 \mathrm{M}$ on $6 \mathrm{ml}$ (wet) AG-50W-X8 resin). The Rb fraction

260 was treated with $29 \mathrm{M} \mathrm{HF}$ to precipitate residual alkaline earths, the supernatant diluted

261 with $1 \mathrm{M} \mathrm{HNO}_{3}$ and the ${ }^{87} \mathrm{Rb} /{ }^{85} \mathrm{Rb}$ measured on the P54 MC-ICPMS. The ${ }^{87} \mathrm{Sr}$ isobar was

262 corrected with the ${ }^{88} \mathrm{Sr} /{ }^{85} \mathrm{Rb}$ ratio, and the instrumental mass bias correction was

263 estimated by natural $\mathrm{Rb}$ standard bracketing between samples. Sr was loaded on a bed of

$264 \mathrm{Ta}_{2} \mathrm{O}_{5}$ with $4 \mathrm{M} \mathrm{HNO}_{3}$ on single degassed Re filaments, and isotope ratios analysed in

265 dynamic mode on the 354 TIMS. The Sr isotopic composition was fractionation-

266 corrected with an exponential law relative to ${ }^{86} \mathrm{Sr} /{ }^{88} \mathrm{Sr}=0.1194$, and is reported as spike-

267 stripped and bias-corrected relative to the accepted value of the NBS-987 standard 
268 (0.71025). The quoted uncertainty for each analysis is the internal standard error; the

269 external reproducibility of the NBS-987 standard over the course of this study was

$270 \quad 0.71026 \pm 3(2 \sigma)$; uncertainty in $\mathrm{Rb}$ and $\mathrm{Sr}$ concentrations and ${ }^{87} \mathrm{Rb} /{ }^{86} \mathrm{Sr}$ are estimated at

$271 \leq 0.2 \%(2 \sigma)$.

272

273 For Sm-Nd isotopic analyses, $100 \mathrm{mg}$ of powders were spiked with ${ }^{149} \mathrm{Sm}-{ }^{150} \mathrm{Nd}$

274 and ${ }^{176} \mathrm{Lu}^{-}{ }^{178} \mathrm{Hf}$ tracers, dissolved with $5 \mathrm{ml} 29 \mathrm{M} \mathrm{HF}+15 \mathrm{M} \mathrm{HNO}_{3}$ (3:2) in Parr pressure

275 vessels at $200^{\circ} \mathrm{C}$ for 72 hours, dried and re-dissolved in $5 \mathrm{ml} 6 \mathrm{M} \mathrm{HCl}$ at $120^{\circ} \mathrm{C}$ for 48

276 hours. After Rb-Sr aliquoting, samples were dried and re-dissolved in $5 \mathrm{ml} 1 \mathrm{M} \mathrm{HCl}+0.1$

$277 \mathrm{M} \mathrm{HF}$ at $120^{\circ} \mathrm{C}$ overnight. Rare earth elements were separated by standard cation

278 exchange chemistry (following $\mathrm{Rb}-\mathrm{Sr}$ and Lu separation by elution in $4 \mathrm{M} \mathrm{HCl}$ on $6 \mathrm{~mm}$

279 i.d. $x 20 \mathrm{~cm}$ columns of AG-50W-X8 resin, $\mathrm{H}^{+}$form, 200-400 mesh); Sm and Nd were

280 separated by cation exchange in $0.2 \mathrm{M}$ a-bishydroxybutyric (methylactic) acid on $2 \mathrm{~mm}$

281 i.d. $x 10 \mathrm{~cm}$ columns of $\mathrm{AG}-50 \mathrm{~W}-\mathrm{X} 8$ resin $\left(\mathrm{NH}_{4}\right)^{+}$form, 200-400 mesh. Sm and Nd

282 isotopes were measured on the P54 MC-ICPMS in static and dynamic Faraday modes,

283 respectively. Instrumental mass fractionation of $\mathrm{Sm}$ and $\mathrm{Nd}$ isotopes was corrected with

284 an exponential law relative to ${ }^{146} \mathrm{Nd} /{ }^{144} \mathrm{Nd}=0.7219$, and ${ }^{152} \mathrm{Sm} /{ }^{147} \mathrm{Sm}=1.783$. The

$285{ }^{143} \mathrm{Nd} /{ }^{144} \mathrm{Nd}$ ratios are reported as spike-stripped and bias-corrected relative to the

286 accepted value of JNdi-1 standard (0.512102). The quoted uncertainty in ${ }^{143} \mathrm{Nd} /{ }^{144} \mathrm{Nd}$

287 represents the last significant digits of the internal measurement standard error for each

288 analysis; the external reproducibility of the JNdi-1 standard over the course of this study

289 was $0.512098 \pm 9(2 \sigma)$; uncertainty in Sm and $\mathrm{Nd}$ concentrations, and ${ }^{147} \mathrm{Sm} /{ }^{144} \mathrm{Nd}$ are

290 estimated at $\leq 0.2 \%(2 \sigma)$. 
Lu and Hf were separated by standard cation exchange chemistry (initial elution

293 of $\mathrm{Hf}$ in $1 \mathrm{M} \mathrm{HCl}+0.1 \mathrm{M} \mathrm{HF}$; Lu following Rb-Sr separation by elution in 4M $\mathrm{HCl}$ on 6

294 mm i.d. x 20 cm columns of AG-50W-X8 resin, $\mathrm{H}^{+}$form, 200-400 mesh, after Patchett

295 and Tatsumoto 1980). Hf was further purified by the method of Munker et al. (2001) on 6

296 mm i.d. x $3.5 \mathrm{~cm}$ columns of Eichrom Ln-spec resin (HDEHP-coated resin, 100-200

297 mesh); Lu was separated from the bulk of $\mathrm{Yb}$ by elution with $2.5 \mathrm{M} \mathrm{HCl}$ on $4 \mathrm{~mm}$ i.d. $\mathrm{x}$

$2987.2 \mathrm{~cm}$ columns of Eichrom Ln-spec resin. Lu and Hf isotopes were measured on the P54

299 MC-ICPMS in static Faraday mode. Instrumental mass fractionation of Hf isotopes was

300 corrected with an exponential law relative to ${ }^{179} \mathrm{Hf} /{ }^{177} \mathrm{Hf}=0.7325$. The ${ }^{176} \mathrm{Lu} /{ }^{177} \mathrm{Hf}$ ratio

301 is reported as spike-stripped and bias-corrected relative to the accepted value of the JMC-

302475 standard (0.282610, Blichert-Toft et al. 1997). The quoted uncertainty for each

303 analysis is the internal standard error; the external reproducibility of the JMC-475

304 standard over the course of this study was $0.282156 \pm 14(2 \sigma)$. Mass fractionation of the

$305{ }^{176} \mathrm{Lu} /{ }^{175} \mathrm{Lu}$ ratio was corrected using the mass bias in ${ }^{173} \mathrm{Yb} /{ }^{174} \mathrm{Yb}$, renormalized to a

306 value of 0.5075 (McCulloch et al. 1977), and the ${ }^{176} \mathrm{Yb}$ isobaric interference was

307 corrected using a value of ${ }^{173} \mathrm{Yb} /{ }^{176} \mathrm{Yb}=0.7848$, which optimally recovered the true

$308{ }^{176} \mathrm{Lu} /{ }^{175} \mathrm{Lu}$ of variably $\mathrm{Yb}$-doped natural and spike Lu standards. Uncertainty in Lu and

$309 \mathrm{Hf}$ concentrations and ${ }^{176} \mathrm{Lu} /{ }^{177} \mathrm{Hf}$ are estimated at $\leq 0.3 \%(2 \sigma)$. Insufficient $\mathrm{Hf}$ was

310 extracted from the carbonatite samples to allow measurement of ${ }^{176} \mathrm{Hf} /{ }^{177} \mathrm{Hf}$, although Lu

311 and Hf concentrations were able to be determined by isotope dilution. For these samples,

312 Hf may have been scavenged by $\mathrm{CaF}_{2}$ precipitates during ion exchange chemistry. 
315 values are given in Table 1.

\section{Results}

320 Petrography.

321 Nepheline syenite gneisses (samples BRM02-1, -02) from Bull's Run consist of

322 granoblastic aggregates of practically unaltered nepheline and perthitic microcline, with

323 lesser green or brown biotite, calcite, titanite and Fe-Ti oxides, and accessory epidote,

324 monazite, apatite and zircon. The gneissic fabric is caused by alignment of dark layers

325 dominated by biotite flakes, abundant euhedral titanite crystals and Fe-Ti oxides. In some

326 samples the abundance of nepheline declines to $<5 \%$ (BRM02-07), and in these rocks

327 albitic plagioclase becomes prominent, in some cases with zoned riebeckitic amphibole

328 (BRM02-06). Bull's Run carbonatites (BRM02-03) are sövitic, and dominated by calcite,

329 with minor brown biotite, apatite and microcline, and accessory albite, pyrochlore and

330 ilmenite. Further petrographic descriptions and details can be found in Scogings (1989)

331 and Scogings and Forster (1989).

332

333 The Tambani DARCs are nepheline monzodiorites dominated by unzoned, fresh

334 albitic plagioclase (70-80\%), with lesser, variably altered nepheline (10-20\%), dark

335 brown to dark greenish brown biotite (10-15\%) and muscovite (2-5\%), with accessory

336 apatite, calcite, Fe-Ti oxides (Ashwal et al. 2007). K-feldspar, alkali amphiboles and 
337 pyroxenes and cancrinite are notably absent. The gneissic fabric is formed by aligned 338 plagioclase and micas.

340 Our samples from the Mongolowe pluton (Chilwa Alkaline Province, Malawi) are

341 all medium grained (1-5 mm), undeformed nepheline syenites, with variable proportions

342 of euhedral to subhedral coarsely exsolved microcline perthite, nepheline, arfvedsonitic

343 amphibole, aegirine and red-brown biotite, with minor sphene, albite, cancrinite and Fe-

344 Ti oxides. Small amounts of sodalite occur in some samples. Plagioclase is absent, except

345 as exsolution products in perthitic feldspars. The major variability in mineralogy relates

346 to the abundance of nepheline (5-15 modal \%) and the color index (volume \% mafic

347 minerals, 2-25 modal \%). Carbonatites are dominated by calcite, with minor Fe-Ti oxides

348 and traces of apatite.

350 Ages.

$351 \quad$ No precise ages are extant for the Bull's Run nepheline syenite or carbonatitic

352 gneisses beyond the results of Nicolaysen and Burger (1965), which yielded $1140 \pm 35$

$353 \mathrm{Ma}$ and $1100 \pm 40 \mathrm{Ma}$ from $\mathrm{U}-\mathrm{Th}-\mathrm{Pb}$ isotopic analyses of a single zircon crystal.

354 Regression of $\mathrm{Rb}-\mathrm{Sr}$ whole-rock data for 11 nepheline syenite gneisses and 5

355 carbonatites, representing our new results combined with those of Scogings (1989) yields

356 an age of $1134 \pm 23 \mathrm{Ma}$, with $\mathrm{I}_{\mathrm{Sr}}=0.70324 \pm 12$ and MSWD $=21$ (Fig. 5), which is

357 coeval with the zircon ages mentioned above. One sample (nepheline syenite gneiss

358 BRM02-7) has an aberrant isotopic composition and is not included in the regression.

359 This sample has lower Rb concentration compared to similar lithologies, and may have 
360 been affected by secondary leaching effects. A regression excluding the carbonatites

361 yields an age of $1117 \pm 31 \mathrm{Ma}\left(\mathrm{I}_{\mathrm{Sr}}=0.70336 \pm 19, \mathrm{MSWD}=5.7\right)$, which is within error

362 of the full data regression. There is insufficient spread in $\mathrm{Sm} / \mathrm{Nd}$ to yield any isochron

363 relationship, and only two samples yielded usable Lu-Hf isotopic data. For this paper we

364 assume an age of magmatic emplacement of $1134 \mathrm{Ma}$, but we recognize that further

365 geochronology is needed to unravel the complex magmatic and metamorphic events in

366 this complex and understudied terrane (e.g. Johnston et al. 2003).

368 For the Tambani body, a magmatic crystallization age of $726 \pm 6 \mathrm{Ma}$ is well 369 established from U-Pb zircon analyses using TIMS and SHRIMP (Ashwal et al. 2007),

370 but Lu-Hf isotopic data for 3 whole-rock samples (Table 1) yield an array corresponding 371 to an age of $582 \pm 18 \mathrm{Ma}\left(\mathrm{MSWD}=0.34, \mathrm{I}_{\mathrm{Hf}}=0.28248 \pm 2, \varepsilon_{\mathrm{Hf}}=+2.49\right.$; Ashwal et al.,

372 2007). This result indicates that the Lu-Hf whole-rock isotopic system is resettable at

373 least at amphibolite grade, but given that zircon megacrysts (which essentially preserve

374 magmatic U-Pb ages) are collinear with the $582 \mathrm{Ma} \mathrm{Lu-Hf}$ array, Ashwal et al. (2007)

375 interpreted the Lu-Hf "isochron" as a mixing line representing the presence in whole-

376 rocks of variable (but generally small) amounts of magmatic zircon. The age of

377 metamorphism, therefore, must be younger than $582 \mathrm{Ma}$, and has been constrained by

378 TIMS analysis of monazite to be $522 \pm 17 \mathrm{Ma}$ (Ashwal et al. 2007).

379

380 Our $\mathrm{Rb}-\mathrm{Sr}$ isotopic data for rocks from the Chilwa Alkaline Province (including

381 pulaskite, foyaite and carbonatite), when regressed with the previously published results

382 of Simonetti and Bell (1994) (including nepheline syenite, carbonatite, olivine 
383 nephelinites and a variety of other alkaline intrusive and extrusive rocks) yield an age of

$384131 \pm 24 \mathrm{Ma}\left(\mathrm{I}_{\mathrm{Sr}}=0.70349 \pm 8, \mathrm{MSWD}=226, \mathrm{n}=21\right)($ Fig. 6). This is within error of all

385 ages determined previously using $\mathrm{K}-\mathrm{Ar}, \mathrm{U}-\mathrm{Pb}$ and fission track methods (summarized in

386 Woolley 2001), which range between $122 \pm 11 \mathrm{Ma}$ and $138 \pm 14 \mathrm{Ma}$. We consider 130

387 Ma as the age of emplacement of our samples from the Chilwa Alkaline Province, and

388 this value is used in all initial ratio calculations discussed below, despite the high MSWD

389 for the isochron shown in Fig. 6.

390

391 Isotopic Compositions

392 Excluding the aberrant sample mentioned above, $\mathrm{I}_{\mathrm{Sr}}$ values for Bull's Run

393 nepheline syenite and carbonatite gneisses, calculated at their presumed time of

394 crystallization $(1134 \mathrm{Ma})$, range from 0.70284 to $0.70351(\mathrm{avg} .=0.70320 \pm 17, \mathrm{n}=16)$,

395 using data from our work and from Scogings (1989). Carbonatite gneisses have slightly

396 lower average $\mathrm{I}_{\mathrm{S}} \mathrm{r}(0.70310 \pm 20, \mathrm{n}=5)$ relative to nepheline syenite gneisses $(0.70325 \pm$

397 15), but the values overlap considerably, and the difference is not significant. Average

$398 \varepsilon_{\mathrm{Nd} 1134}$ and $\varepsilon_{\mathrm{Hf} 1134}$ values are $+3.3 \pm 2$ and $-1.1 \pm 2$, respectively (Table 1$)$. We failed to

399 recover Hf isotopic data from carbonatite gneiss sample BRM02-3.

400

$401 \quad$ For the Tambani body, $\mathrm{I}_{\mathrm{Sr}}$ values calculated at the crystallization age of $726 \mathrm{Ma}$

402 range from 0.70285 to $0.70298(\operatorname{avg} .=0.70292 \pm 6, \mathrm{n}=3) ; \varepsilon_{\mathrm{Nd}}$ values range from 3.57 to

$4033.84($ avg. $=3.70 \pm 0.14, \mathrm{n}=3)($ Table 1$)$. Due to metamorphic resetting and isochron

404 rotation (Ashwal et al. 2007), the initial Hf isotopic composition of two nepheline syenite

405 gneiss samples with high ${ }^{176} \mathrm{Lu} /{ }^{177} \mathrm{Hf}(\mathrm{TH}-2, \mathrm{TH}-5)$ are unusually low $\left(\varepsilon_{\mathrm{Hf} 726}=-3.61-\right.$ 
3.11). A better estimate of primary initial Hf values is given by samples with low ${ }^{176} \mathrm{Lu} /{ }^{177} \mathrm{Hf}$, such as zircon megacrysts and nepheline syenite sample $\mathrm{TH}-3$, which yield $\varepsilon_{\mathrm{Hf}} 726$ values of 4.36 to $5.51(\mathrm{avg} .=4.96 \pm 0.50, \mathrm{n}=4)$.

411 Alkaline Province, including our data and those of Simonetti and Bell (1994) and Bizimis

412 et al. (2003), form a cluster of compositions on a plot of $\mathrm{I}_{\mathrm{Sr}}$ vs. $\varepsilon_{\mathrm{Nd}}$ (Fig. 7), with values of $413 \mathrm{I}_{\mathrm{Sr}}$ ranging from 0.70319 to $0.70384(\mathrm{avg} .=0.70348 \pm 18, \mathrm{n}=22)$, and $\varepsilon_{\mathrm{Nd}}$ values range

414 from 2.52 to 4.56 (avg. $=3.50 \pm 0.61, \mathrm{n}=21$ ), excluding one aberrant ijolite sample with

$415 \varepsilon_{\mathrm{Nd}}=-0.24$, Simonetti and Bell 1994). Carbonatite samples seem to have a slightly higher

416 average $\varepsilon_{\mathrm{Nd}}$ value $(3.79 \pm 0.43, \mathrm{n}=13)$ compared to nepheline syenites $\left(\varepsilon_{\mathrm{Nd}}=3.04 \pm 0.58\right.$,

$417 \mathrm{n}=8$ ), although there is some overlap. Initial Hf values for nepheline syenites range from

$418 \varepsilon_{\mathrm{Hf} 130}=1.09$ to 2.50 (avg. $=1.60 \pm 0.78, \mathrm{n}=3$ ). As with Bull's Run samples, we were not

419 able to acquire Hf isotopic data from Chilwa carbonatites, but Bizimis et al. (2003)

420 reported results for a single carbonatite sample and a replicate that gave $\varepsilon_{\mathrm{Hf} 130}=7.37$ to

421 7.83. Chilwa carbonatites, therefore, appear to have both higher $\varepsilon_{\mathrm{Hf}}$ and $\varepsilon_{\mathrm{Nd}}$ relative to

422 nepheline syenites, but more data are needed to confirm this.

\section{Mixing Calculations}

We carried out mixing calculations to evaluate the possibility that the isotopic 
429 for by blending between known mantle sources and older, deformed ARCs (DARCs) that

430 were subducted prior to and during continent-continent collisional events, as proposed by

431 Burke et al. (2003). Specifically, our calculations were aimed at testing the possibility

432 that the Sr-Nd-Hf isotopic compositions of the sources to the $130 \mathrm{Ma}$ Chilwa nepheline

433 syenites and carbonatites could be modelled as mixtures of a depleted mantle (DM)

434 component and an older DARC component represented by the $1134 \mathrm{Ma}$ Bull's Run

435 nepheline syenites. We stress that we are not suggesting that Bull's Run type material

436 represents a specific component in the Chilwa source; we are merely exploring the

437 possibility that older DARC material could contribute to such a source. Results are shown

438 in Fig. 7, where the isotopic compositions of all considered samples and possible sources

439 were adjusted to their positions at $130 \mathrm{Ma}$, the age of the Chilwa alkaline province. For

440 the DM component we used the concentration data for average DM given by Workman

441 and Hart (2005) and the isotopic composition for Sr, Nd and Hf given by Rehkamper and

442 Hofmann (1997), Peucat et al. (1989) and Griffin et al. (2000), respectively. Based on our

443 data and those of Scogings (1989), the Bull's Run nepheline syenites will have variable

444 isotopic compositions at $130 \mathrm{Ma}$, especially for Sr. Since Scogings reported only Rb-Sr

445 isotopic data we assumed an average $\varepsilon_{\mathrm{Nd} 130}$ value of -11.37 based on our own results. For

446 concentrations of Bull's Run nepheline syenites, we used average values of $\mathrm{Sr}=470$

447 ppm, $\mathrm{Nd}=50 \mathrm{ppm}$ and $\mathrm{Hf}=16 \mathrm{ppm}$ based on our own data and those of Scogings (1989)

448 as well as from a larger database of late Precambrian nepheline syenites from the North

449 Nyasa Alkaline Province of Malawi (Eby et al. 1998). A Bull's Run carbonatite

450 component is shown for comparison, but is not modelled because we consider the volume 
451 of carbonatites to be insignificant relative to the nepheline syenite components in most

452 ARC and DARC occurrences.

453

454 The results show that the isotopic compositions of Chilwa sources can be

455 successfully modelled as mixtures of DM with $\sim 0.4-0.6 \%$ of Bull's Run nepheline

456 syenites, using the mixing equations of DePaolo and Wasserburg (1979). The models also

457 account for the isotopic variability of Chilwa nepheline syenite and carbonatite samples

458 (Fig. 7). The small amount of DARC material required is due to their concentrations of

$459 \mathrm{Sr}, \mathrm{Nd}$ and $\mathrm{Hf}$, which are $\sim 50-100$ times larger than those of the DM component. The

460 most successful models are those in which the DARC components have $\mathrm{Sr} / \mathrm{Nd} \sim 10$ and

$461 \mathrm{Nd} / \mathrm{Hf} \sim 4-5$; these ratios are consistent with those of most nepheline syenites, from

462 worldwide compilations. Too few data exist to evaluate the suitability of younger DARC

463 material as a mixing component, such as the 582 Ma Tambani nepheline syenites, but

464 preliminary mixing calculations suggest that such material, blended with DM, would

465 need to be present in amounts of about $1-2 \%$.

468 Discussion

470 Our mixing calculations constitute permissive, but not demonstrative evidence for

471 the sources of ARC magmatism as representing mixtures of recognized lithospheric

472 mantle materials such as DM, with subducted, older DARC materials. This model,

473 therefore, serves as a viable alternative to the perhaps more traditional view that involves 
474 an entirely sub-lithospheric source for such magmatism, in which the sources represent

475 mixtures of enriched, asthenospheric mantle components such as HIMU, EM1 and/or

476 FOZO (e.g. Bell and Simonetti 2010). We cannot specify whether the two components

477 we propose (DM and DARC materials) become blended in the upper mantle, or whether

478 they remain physically discrete and produce separate partial melts that mix. However, we

479 envisage a similar process to that which produces ocean-island basalt melts from mantle

480 heterogeneities caused, for example, by subduction of oceanic lithosphere (e.g. Hofmann,

481 1997). The physical problem of deriving hybrid melts from heterogeneous mantle sources

482 was addressed in studies such as that of Kogiso et al. (2004), who investigated the length-

483 scales of mantle heterogeneities with respect to the relative time-scales between diffusion

484 and melt segregation. More work along these lines is needed.

Arguments against a lithospheric source for ARC magmas, as summarized by Bell

487 and Simonetti (2010), included: (1) their spatial and temporal association with plume-

488 related large igneous provinces (LIPs) such as Deccan and Paraná, (2) “primitive” noble

489 gas signatures in some carbonatites, (3) the similarity of putative mantle sources (HIMU,

490 EM1, FOZO) to those of some ocean island basalts (OIB), and (4) the apparently simple

$491 \mathrm{Rb} / \mathrm{Sr}$ and $\mathrm{Sm} / \mathrm{Nd}$ evolution lines of carbonatites in some regions (e.g. eastern Canada,

492 Fennoscandia). We address these points below.

493

494 We do not dispute that some ARC magmas were produced as a result of mantle

495 plumes, but these are volumetrically subsidiary, or at least less well characterized than

496 those outcropping in intracontinental rifts (Bailey 1972, 1974, 1992; Burke et al. 2003). 
497 Aside from the rare, obviously plume-related ARCs in ocean islands such as Cape Verde,

498 the Canary Islands, and Hawaii (Gerlach 1988; Hoernle et al. 2002; Dixon et al. 2008),

499 well known continental plume-related ARCs include those of the Monteregian Hills,

500 Quebec (e.g. Eby 1994), whose association with a continental hotspot track was outlined

501 by Sleep (1990). However, for continental examples, including those associated with

502 intracontinental LIPs (e.g. Ernst and Bell 2010) we would envisage an entirely

503 lithospheric source for the ARC magmas, with the principal components of DM and

504 subducted, older DARC material. Burke et al. (2008a) explained how the plume-related,

505 Cretaceous Monteregian ARCs could be accounted for using the ARC-DARC model,

506 with the subducted DARC material being represented by Proterozoic nepheline syenites

507 and carbonatites of the Bancroft domain, equivalents of which may have been taken into

508 the mantle lithosphere by Grenvillian collisional events. In our view, mantle plumes may

509 provide the heat, but little to none of the material involved in melting the lithosphere to

510 produce ARCs.

512 Noble gas isotopic compositions of Precambrian to Cretaceous carbonatites from

513 Brazil, Canada and Russia (e.g. Marty et al. 1998; Sasada et al. 1997; Tolstikhin et al.

514 2002) have been interpreted to indicate derivation from a deep, sub-lithospheric,

515 primordial mantle source, similar to that advocated for many plume-related products (e.g.

516 Graham 2002) or from the large low shear wave velocity provinces (LLSVPs) situated at

517 the core-mantle boundary (Burke et al. 2008b). For example, Marty et al. (1998) reported

$518{ }^{3} \mathrm{He} /{ }^{4} \mathrm{He}$ of up to $19 \mathrm{R}_{\mathrm{A}}\left(\right.$ where $\mathrm{R}_{\mathrm{A}}=$ atmospheric ${ }^{3} \mathrm{He} /{ }^{4} \mathrm{He}$ ) for a component in Devonian

519 carbonatites from the Kola Peninsula (Burke et al. 2007), which would seemingly 
520 represent a strong argument for the involvement of a signature from the deep mantle. We

521 suggest that if ARC magmas contain a plume-related noble gas isotopic signature, the

522 gases may have been added to the mantle lithosphere by diffusion or carried with aqueous

523 and/or carbonic fluids that helped to induce melt production. Indeed, Tolstikhin et al.

524 (2002) have estimated that $<2 \%$ of the noble gas budget in Kola ARC material could be

525 derived from a deep plume source, with the vast majority $(>98 \%)$ representing a shallow

526 (i.e. lithospheric) mantle component. They state, therefore, that "a minor contribution

527 from the plume implies that it could only stimulate metasomatism of the subcontinental

528 lithosphere whereas melts from the upper mantle play the major role..." (Tolstikhin et al.

529 2002, p. 898). We note that all of the ARC occurrences where "primordial" (i.e. with

530 deep) noble gas signatures have been proposed are those associated with well-known

531 mantle plumes, and none are from intracontinental rifts. As shown by isotopic

532 compositions of $\mathrm{He}, \mathrm{N}_{2}, \mathrm{C}, \mathrm{Ar}$ and Ne, the gases presently being emitted from the active

533 natrocarbonatite volcano Oldoinyo Lengai (Tanzania), associated with the East African

534 Rift, resemble those of MORB, and are indistinguishable from the subcontinental

535 lithospheric mantle (Fischer et al. 2009). We conclude that extant noble gas isotopic and

536 concentration measurements in ARC materials do not preclude their origin as partial

537 melts of lithospheric mantle sources.

539 We do dispute the interpretation of young (or even old) ARC isotopic signatures

540 as representing mixtures between HIMU and EM1 source components, and the inference

541 that these mantle components underlay large areas of the continental lithosphere, such as

542 in East Africa. Rather, the HIMU and EM1 components are rare, and are restricted to a 
543 few places in the oceanic mantle (e.g. Stracke et al. 2005). In our view, arrays formed by

544 different ARC occurrences on diagrams of initial isotopic compositions (e.g. $\mathrm{I}_{\mathrm{Sr}} \mathrm{Vs} . \varepsilon_{\mathrm{Nd}}$ )

545 would represent variable amounts of source components DM and older DARC material.

546 Some part of the observed isotopic variability might also be caused by incorporation of

547 DARC material of different ages. The DM component we envisage is usually the

548 dominant one in ARC isotopic signatures (Fig. 7), is compositionally similar to that of the

549 shallow oceanic mantle (e.g. Carlson et al. 2005), and although there is abundant

550 evidence for local metasomatism, depleted mantle typically dominates the sub-

551 continental mantle lithosphere (SCLM) (e.g. Griffin et al. 2003). The simple evolution

552 lines of $\mathrm{ARC}$ rocks on age vs. $\mathrm{I}_{\mathrm{Sr}}$ or $\varepsilon_{\mathrm{Nd}}$ diagrams that imply an ancient $(\sim 3 \mathrm{Ga})$ isolated

553 mantle source with low $\mathrm{Rb} / \mathrm{Sr} \sim 0.02$ and high $\mathrm{Sm} / \mathrm{Nd} \sim 0.36$ precisely track the $\mathrm{DM}$

554 component in the SCLM, as originally suggested by Bell et al. (1982) and Bell and

555 Blenkinsop (1987a). Dispersion of isotopic compositions in such diagrams (e.g. Fig. 2 in

556 Bell and Simonetti, 2010) is likely caused by variable, but small involvement of DARC

557 source components. We would argue, therefore, that the alleged similarity of ARC

558 isotopic signatures to OIB sources is, therefore, more apparent than real, and should not

559 be used to infer the "widespread" presence of oceanic source components in the

560 asthenosphere below continents.

561

562 The model we have successfully tested, that ARC magmas could be

563 lithospherically-derived from mixtures of depleted mantle and subducted DARC

564 materials, accounts for the repeated emplacement of ARC and DARC magmas, over long

565 time periods, in the same places. Wilson cycle studies (e.g. Wilson 1966) show that 
566 intracontinental rifts commonly form above previously-formed suture zones, and

567 examples focused on the ARC-DARC hypothesis include Peninsular India (Leelanandam

568 et al. 2006), northwestern Russia and northern Norway (Burke et al. 2007) and east-

569 central Africa (Burke et al. 2003). The triggering mechanism for small-degree, alkaline

570 magmatism is adiabatic decompression melting during uplift and extension of mantle

571 lithosphere (e.g. Bailey 1983; McKenzie and Bickle 1988; Pedersen and Ro 1992; Keen

572 et al. 1994). Heat derived from deep mantle plumes may also be important, as a link

573 between plumes and some intracontinental rifts is well established (Wilson 1973; White

574 and McKenzie 1989; Hill 1991)

575

576 Acknowledgements

577

578 We thank Paul Dirks, who helped arrange our field work in Malawi, and Mike

579 Moles and Brian Chiombe for their assistance once we got there. Guy Charlesworth

580 shared his knowledge and resources about the Bull's Run occurrence in Natal, and Mike

581 Watkeys and Steve McCourt accompanied us in the field. Reviews by Stephen Johnston,

582 Lang Farmer and two anonymous individuals substantially improved our paper. This

583 work was supported by National Research Council grants to L.D. Ashwal. 


\section{References}

587 Ashwal, L.D., Armstrong, R.A., Roberts, R.J., Schmitz, M.D., Corfu, F., Hetherington,

588 C.J., Burke, K. and Gerber, M. 2007. Geochronology of large zircons from nepheline-

589 bearing gneisses as constraints on tectonic setting: an example from southern Malawi.

590 Contributions to Mineralogy and Petrology, 153: 389-403.

591

592 Bailey, D.K. 1974. Continental rifting and alkaline magmatism. In The Alkaline Rocks.

593 Edited by H. Sorenson. Wiley, New York, pp. 148-159.

594

595 Bailey, D.K. 1977. Lithospheric control of continental rift magmatism. Geological

596 Society of London Journal, 133: 103-108.

598 Bailey, D.K. 1983. The chemical and thermal evolution of rifts. Tectonophysics 94: 585599597.

600

601 Bailey, D.K. 1992. Episodic alkaline activity across Africa: Implications for the causes of 602 continental break-up. In Magmatism and the Causes of Continental Break-up. Edited by

603 B.C. Storey et al. Geological Society of London Special Publication 68, pp. 91-98. 604

605 Bell, K. 2001. Carbonatites: relationships to mantle-plume activity. In Mantle Plumes:

606 Their Identification Through Time. Edited by R.E. Ernst and K.L. Buchan. Geological 607 Society of America Special Paper 352, pp. 267-290. 
609 Bell, K. and Blenknsop, J. 1987a. Archean depleted mantle- evidence from Nd and Sr

610 initial isotopic ratios of carbonatites. Geochimica et Cosmochimica Acta, 51: 291-298.

611

612 Bell, K. and Blenkinsop, J. 1987b. Nd and Sr isotopic compositions of East African

613 carbonatites: Implications for mantle heterogeneity. Geology, 15: 99-102.

614

615 Bell, K. and Blenknsop, J. 1989. Neodymium and strontium isotope geochemistry of 616 carbonatites. In Carbonatites: Genesis and Evolution. Edited by K. Bell. Unwin Hyman, 617 London, pp. 278-300.

618

619 Bell, K. and Simonetti, A. 2010. Source of parental melts to carbonatites- critical isotopic 620 constraints. Mineralogy and Petrology, 98: 77-89.

621

622 Bell, K. and Tilton, G.R. 2001. Nd, Pb and Sr isotopic compositions of East African

623 carbonatites: Evidence for mantle mixing and plume inhomogeneity. Journal of

624 Petrology, 42: 1927-1945.

625

626 Bell, K. and Tilton, G.R. 2002. Probing the mantle: The story from carbonatites. EOS, 627 83: $273-277$.

628

629 Bell, K., Blenkinsop, J., Cole, T.J.S. and Menagh, D.P. 1982. Evidence from Sr isotopes

630 for long-lived heterogeneities in the upper mantle. Nature, 298: 251-253. 
632 Bernard-Griffiths, J., Peucat, J.-J., Fourcade, S., Kienast, J.-R. and Ouzegane, K. 1988.

633 Origin and evolution of 2 Ga old carbonatite complex (Ihouhaouene, Ahaggar, Algeria):

$634 \mathrm{Nd}$ and Sr isotopic evidence. Contributions to Mineralogy and Petrology, 100: 339-348.

635

636 Bizimis, M., Salters, V.J.M. and Dawson, J.B. 2003. The brevity of carbonatite sources in

637 the mantle: evidence from Hf isotopes. Contributions to Mineralogy and Petrology. 145:

$638 \quad 281-300$

639

640 Bizzarro, M., Simonetti, A., Stevenson, R.K. and David, J. 2002. Hf isotope evidence for 641 a hidden mantle reservoir. Geology, 30: 771-774.

642

643 Blichert-Toft, J., Chauvel, C. and Albarède, F. 1997. Separation of Hf and Lu for high

644 precision isotope analysis of rock samples by magnetic sector-multiple collector ICP-MS.

645 Contributions to Mineralogy and Petrology, 127: 248-260.

646

647 Burke, K., Ashwal, L.D. and Webb, S.J. 2003. New way to map old sutures using

648 deformed alkaline rocks and carbonatites. Geology, 31: 391-394.

649

650 Burke, K., Roberts, D. and Ashwal, L.D. 2007. Alkaline rocks and carbonatites of

651 northwestern Russia and northern Norway: Linked Wilson cycle records extending over

652 two billion years. Tectonics 26: TC4015, doi:10.1029/2006TC002052. 
654 Burke, K., Khan, S.D. and Mart, R.W. 2008a. Grenville Province and Monteregian

655 carbonatite and nepheline syenite distribution related to rifting, collision and plume

656 passage. Geology, 36: 983-986.

657

658 Burke, K., Steinberger, B., Torsvik, T.H. and Smethurst, M.A. 2008b. Plume generation

659 zones at the margins of large low shear velocity provinces on the core-mantle boundary.

660 Earth and Planetary Science Letters, 265: 49-60.

661

662 Carlson, R.W., Pearson, D.G. and James, D.E. 2005. Physical, chemical and

663 chronological characteristics of continental mantle. Review of Geophysics, 43: RG1001, 664 doi:10.1029/2004RG000156.

665

666 Charlesworth, E.G. 1981. Tectonics and metamorphism of the northern margin of the

667 Namaqua-Natal mobile Belt near Eshowe, Natal. Ph.D. Thesis, Department of Geology,

668 University of Natal, Durban, 433 pp,

669

670 Cooper, W.G.G. and Bloomfield, K. 1961. The geology of the Tambani-Salambidwe area

671 (with accompanying geological map, scale 1:100,000). Bulletin 13, Geological Survey of

672 Nyasaland, $63 \mathrm{pp}$.

673

674 Deines, P. 1989. Stable isotope variations in carbonatites. In Carbonatites: Genesis and

675 Evolution. Edited by K. Bell. Unwin Hyman, London, pp. 301-359.

676 
677 DePaolo, D.J. and Wasserburg, G.J. 1979. Petrogenetic mixing models and Nd-Sr

678 isotopic patterns. Geochimica et Cosmochimica Acta, 43: 615-628.

679

680 DePaolo, D.J., Linn, A.M. and Schubert, G. 1991. The continental crustal age

681 distribution: methods of determining mantle separation ages from $\mathrm{Sm}-\mathrm{Nd}$ isotopic data

682 and application to the southwestern United States. Journal of Geophysical Research, 96:

$683 \quad 2071-2088$.

684

685 Dixon, J., Clague, D.A., Cousens, B.., Monsalve, M.L. and Uhl, J. (2008) Carbonatite

686 and silicate melt metasomatism of the mantle surrounding the Hawaiian plume: Evidence

687 from volatiles, trace elements and radiogenic isotopes in rejuvenated-stage lavas from

688 Nihau, Hawaii. Geochemistry Geophysics Geosystems, 9, doi: 10.1029/2008GC002076.

689

690 Eby, G.N. 1994. Monteregian Hills 1. Petrography, major and trace element

691 geochemistry, and strontium isotopic chemistry of the western intrusions: Mounts Royal,

692 St. Bruno, and Johnson. Journal of Petrology, 25: 421-452.

693

694 Eby, G.N., Woolley, A.R., Din, V. and Platt, G. 1998. Geochemistry and petrogenesis of

695 nepheline syenites: Kasungu, Ilomba, and Ulindi nepheline syenite intrusions, North

696 Nyasa Alkaline Province, Malawi. Journal of Petrology, 39: 1405-1424.

697 
698 Eriksson, S.C. 1989. Phalaborwa: a saga of magmatism, metasomatism and miscibility.

699 In Carbonatites: Genesis and Evolution. Edited by K. Bell. Unwin Hyman, London, pp.

$700 \quad 221-254$

701

702 Ernst, R.E. and Bell, K. 2010. Large igneous provinces (LIPs) and carbonatites.

703 Mineralogy and Petrology, 98: 55-76.

704

705 Feather, C.E. and Willis, J.P. 1976. A simple method for background and matrix

706 correction of spectral peaks in trace element determination by X-ray fluorescence

707 spectrometry. X-ray Spectrometry, 5: 41-48.

708

709 Fischer, T.P., Burnard, P., Marty, B., Hilton, D.R., Füri, E., Palhol, F., Sharp, Z.D. and

710 Mangasini. F. 2009. Upper-mantle volatile chemistry at Oldoinyo Lengai volcano and the

711 origin of carbonatites. Nature, 459: 77-80.

712

713 Garson, M.S. 1965, Carbonatites in southern Malawi. Geological Survey of Malawi

714 Bulletin 15, 128 pp.

715

716 Garson, M.S. 1966. Carbonatites in Malawi. In Carbonatites. Edited by O.F, Tuttle and J.

717 Gittins. John Wiley, New York, pp. 33-71.

718

719 Garson, M.S. and Smith W.C. 1958. Chilwa Island. Geological Survey of Nyasaland

720 Memoir 1, 127 pp. 
722 Gerlach, D.C., Cliff, R.A., Davies, G.R., Norry, M. and Hodgson, N. 1988. Magma

723 sources of the Cape Verdes archipelago: isotopic and trace element constraints.

724 Geochimica et Cosmochimica Acta, 52, 2979-2992.

725

726 Graham, D.W. 2002. Noble gas isotope geochemistry of mid-ocean ridge and ocean

727 island basalts: Characterization of mantle source reservoirs. In Noble Gases in

728 Geochemistry and Cosmochemistry. Edited by D. Porcelli, C.J. Ballentine and R. Wieler.

729 Reviews in Mineralogy and Geochemistry 47, pp. 247-318.

730

731 Griffin, W.L., O’Reilly, S.Y., Natapov, L.M. and Ryan, C.G. (2003) The evolution of

732 lithospheric mantle beneath the Kalahari craton and its margins. Lithos, 71: 215-241.

734 Griffin, W.L., Pearson, N.J., Belousova, E., Jackson, S.E., van Achterbergh, E., O’Reilly,

735 S. and Shee, S.R. 2000. The Hf isotope composition of cratonic mantle: LAM-MC-

736 ICPMS analysis of zircon megacrysts in kimberlites. Geochimica et Cosmochimica Acta,

737 64: 133-147.

738

739 Hill, R.I. 1991. Starting plumes and continental break-up. Earth and Planetary Science

$740 \quad$ Letters 104: 398-416.

741

742 Hoernle, K., Tilton, G., Le Bas, M.J., Duggen, S. and Garbe-Schönberg, D. 2002.

743 Geochemistry of oceanic carbonatites compared with continental carbonatites: mantle 
744 recycling of oceanic crustal carbonate. Contributions to Mineralogy and Petrology, 142,

$745 \quad 250-542$.

746

747 Hofmann, A.W. 1997. Mantle geochemistry: the message from oceanic volcanism.

$748 \quad$ Nature, 385, 219-229.

749

750

751 Johnston, S.T., McCourt, S., Bisnath, A. and Mitchell, A.A. 2003. The Tugela Terrane,

752 Natal Belt: Kibaran magmatism and tectonism along the southeast margin of the

753 Kaapvaal Craton. South African Journal of Geology, 106, 85-97.

754

755 Keen, C.E., Courtney, R.C., Dehler, S.A. and Williamson, M.-C. 1994. Decompression

756 melting at rifted margins: comparison of model predictions with the distribution of

757 igneous rocks on the eastern Canadian margin. Earth and Planetary Science Letters 121:

$758 \quad 403-416$

759

760 Kogiso, T., Hirschmann, M.M. and Reiners, P.W. 2004. Length scales of mantle

761 heterogeneities and their relationship to ocean island basalt geochemistry. Geochimica et

762 Cosmochimica Acta, 68, 345-360.

763

764 Kwon, S.-T., Tilton, G.R. and Grunenfelder, M.H. 1989. Lead isotope relationships in

765 carbonatites and alkalic complexes: an overview. In Carbonatites: Genesis and Evolution.

766 Edited by K. Bell. Unwin Hyman, London, pp. 360-387. 
768 Lameyre, J. and Lasserre, M. 1967. Étude géochronologique des syenites alcalines et 769 néphélinitiques du massif annulaire de Hassi-el-Fogra (Mauritanie du Nord). Comptes

770 Rendus des l'Académie des Sciences, Paris, 265D: 733-736.

771

772 Lasserre, M. and Soba, D. 1976. Age liberien des granodiorites et des gneiss a pyroxene

773 du Cameroun meridional. Bulletin du Bureau de Recherches Géologiques et Minières,

774 Paris, 4: 17-32.

775

776 Leelanandam, C., Burke, K., Ashwal, L.D. and Webb, S.J. 2006. Proterozoic mountain

777 building in Peninsular India: an analysis based primarily on alkaline rock distribution.

778 Geological Magazine 143: 195-212.

779

780 Marty, B., Tolstikhin, I., Kamensky, I.L., Nivin, V., Balaganskaya, E. and Zimmermann,

781 J.-L. (1998) Plume-derived rare gases in 380 Ma carbonatites from the Kola region

782 (Russia) and the argon isotopic composition in the deep mantle. Earth and Planetary

783 Science Letters, 164: 179-192.

784

785 McCulloch, M.T., Rosman, K.J.R. and De Laeter, J.R. 1977. The isotopic and elemental

786 abundance of ytterbium in meteorites and terrestrial samples. Geochimica et

787 Cosmochimica Acta, 41: 1703-1707. 
789 McKenzie, D. and Bickle, M.J. 1988. The volume and composition of melt generated by

790 extension of the lithosphere. Journal of Petrology 29, 625-679.

791

792 Munker, C., Weyer, S., Scherer, E. and Mezger, K. 2001. Separation of high field

793 strength elements (Nb, Ta, Zr, Hf) and Lu from rock samples for MC-ICPMS

794 measurements. Geochemistry Geophysics Geosystems, 2, doi:10.1029/2001GC000183.

795

796 Nelson, D.R., Chivas, A.R., Chappell, B.W. and McCulloch, M.T. 1988. Geochemical

797 and isotopic systematics in carbonatites and implications for the evolution of ocean-

798 island sources. Geochimica et Cosmochimica Acta, 52: 1-17.

799

800 Nicolaysen, L.O. and Burger, A.J. 1965. Note on an extensive zone of 1000 million-year

801 old metamorphic and igneous rocks in southern Africa. Sciences de la Terre 10, no. 3-4, $802 \quad 497-516$.

803

804 Norrish, K. and Hutton, J.T. 1969. An accurate X-ray spectrographic method for the

805 analysis of a wide range of geological samples. Geochimica et Cosmochimica Acta, 33:

806 431-453.

807

808 Patchett, P.J. and Tatsumoto, M. 1980. A routine high-precision method for Lu-Hf

809 isotope geochemistry and chronology. Contributions to Mineralogy and Petrology, 75:

$810 \quad 263-267$.

811 
812 Pedersen, T. and Ro, H.E. 1992. Finite duration extension and decompression melting.

813 Earth and Planetary Science Letters 113: 15-22.

814

815 Peucat, J.J., Vidal, P., Bernard-Griffiths, J. and Condie, K.C. 1989. Sr, Nd and Pb

816 isotopic systematics in the Archean low- to high-grade transition zone of southern India:

817 syn-accretion vs. post-accretion granulites. Journal of Geology, 97: 537-549.

818

819 Rehkamper, M. and Hofmann, A.W. 1997. Recycled ocean crust and sediment in Indian

820 Ocean MORB. Earth and Planetary Science Letters, 147: 93-106.

821

822 Sasada, T., Hiyagon, H., Bell, K. and Ebihara, M. 1997. Mantle-derived noble gases in

823 carbonatites. Geochimica et Cosmochimica Acta, 61: 1219-1228.

824

825 Scogings, A.J. 1989. Alkaline intrusives from the Tugela Terrane, Natal Metamorphic

826 Province. Ph.D. Thesis, Department of Geology, University of Durban, Westville, 500

827 pp.

828

829 Scogings, A.J. and Forster, I.F. 1989. Gneissose carbonatites in the Bull's Run Complex,

830 Natal. South African Journal of Geology, 92: 1-10.

831

832 Simonetti, A. and Bell, K. 1994. Isotopic and geochemical investigation of the Chilwa

833 Island carbonatite complex, Malawi: Evidence for a depleted mantle source region, liquid

834 immiscibility, and open-system behaviour. Journal of Petrology, 35: 1597-1621. 
836 Sleep, N.H. 1990. Monteregian hotspot track: A long-lived mantle plume. Journal of

837 Geophysical Research. 95: 21983-21990.

838

839 Stracke, A., Hofmann, A.W. and Hart, S.R. 2005. FOZO, HIMU and the rest of the

840 mantle zoo. Geochemistry, Geophysics and Geosystems, 6: 1-20. doi:

$841 \quad 10.1029 / 2004 G C 000824$.

842

843 Tolstikhin, I.N., Kamensky, I.L., Marty, B., Nivin, V.A., Vetrin, V.R., Balaganskaya,

844 E.G., Ikorsky, S.V., Gannibal, M.A., Weiss, D., Verhulst, A. and Demaiffe, D. 2002.

845 Rare gas isotopes and parent trace elements in ultrabasic-alkaline-carbonatite complexes,

846 Kola Peninsula: Identification of lower mantle plume component. Geochimica et

847 Cosmochimica Acta, 66: 881-901.

848

849 Walraven, F., Frick, C. and Lubala, R.T. 1992. Pb-isotope geochronology of the Schiel

850 complex, northern Transvaal, South Africa. Journal of African Earth Sciences, 15: 103-

851110.

852

853 White R. and McKenzie, D. 1989. Magmatism at rift zones: The generation of volcanic

854 continental margins and flood basalts. Journal of Geophysical Research 94: 7685-7729.

855

856 Wilson, J.T. 1966. Did the Atlantic close and then re-open? Nature 211: 676-681. 
858 Wilson, J.T. 1973. Mantle plumes and plate motions. Tectonophysics 19: 149-164.

859

860 Woolley, A.R. 1969. Some aspects of fenitization with particular reference to Chilwa

861 Island and Kangankunde, Malawi. Bulletin of the British Museum (Natural History),

862 Mineralogy 2: 189-219.

863

864 Woolley, A.R. 1991. The Chilwa Alkaline Province of Malawi: a review. In Magmatism

865 in Extensional Structural Settings: the Phanerozoic African Plate. Edited by A.B.

866 Kampunzu, A.B. and R.T. Lubala. Springer-Verlag, Berlin, pp. 377-409.

867

868 Woolley, A.R. 2001. Alkaline rocks and carbonatites of the world: Part 3, Africa.

869 Geological Society of London, $372 \mathrm{pp}$.

870

871 Workman, R.K. and Hart, S.R. 2005. Major and trace element composition of the

872 depleted MORB mantle (DMM). Earth and Planetary Science Letters, 231: 53-72.

873

874

875

876

877 


\section{$878 \quad$ Figure Captions}

879

880 Fig. 1. Locations of deformed and undeformed alkaline rocks and carbonatites of Africa, 881 compiled from the catalogue of Woolley (2001). The three occurrences for which data are 882 reported upon in this study include Bull's Run, South Africa (Fig. 2), Tambani, Malawi 883 (Fig. 3) and Chilwa, Malawi (Fig. 4).

884

885 Fig. 2. Geological map of the Bull's Run Complex, Natal, South Africa, showing 886 locations of analysed samples. Original mapping is by Charlesworth (1981) and Scogings 887 and Forster (1989).

888

889 Fig. 3. Geological map of the Tambani - Salambidwe area of southern Malawi, showing 890 the Tambani sample locality reported upon in this paper. About $15 \mathrm{~km}$ southwest of the 891726 Ma Tambani body lies the post-Triassic Salambidwe intrusion, representing an 892 example of recurrent alkaline magmatism in a spatially restricted area (Burke et al. 2003).

893 Original mapping is by Cooper and Bloomfield (1961)

894

895 Fig. 4. Geological map of the Chilwa Alkaline Province of southern Malawi, showing 896 location of samples from the Mongolowe nepheline syenite body and the Chilwa Island 897 carbonatite. 
899 Fig. 5. Rb-Sr isochron diagram showing regression of isotopic data for Bull's Run (South

900 Africa) nepheline syenite gneisses and carbonatites. Analytical uncertainties $(2 \sigma)$ are

901 smaller than the symbol sizes. Data sources: this study and Scogings (1989).

902

903 Fig. 6. Rb-Sr isochron diagram showing regression of isotopic data for nepheline

904 syenites, carbonatites, olivine nephelinites, camptonites, alnöites and ijolites from the

905 Chilwa Alkaline Province, Malawi. Analytical uncertainties $(2 \sigma)$ are smaller than the

906 symbol sizes. Data sources: this study and Simonetti and Bell (1994). The array yields an

907 errorchron with high MSWD, but the resulting age of $131 \pm 24$ Ma falls within the range

908 of ages for the Chilwa Alkaline Province (122 - $138 \mathrm{Ma})$ as summarized by Woolley

909 (2001), and is equivalent to the 130 Ma age for rocks of the Province as used by

910 Simonetti and Bell (1994).

911

912 Fig. 7. Sr, Nd and Hf isotopic data for southern African alkaline rocks and carbonatites,

913 showing positions of putative mantle source components DM, HIMU, FOZO and EM1.

914 All data are corrected to the emplacement age of 130 Ma for the Chilwa Alkaline

915 Complex. See text for additional details, including data sources. Symbols are as follows:

916 red $=$ Chilwa nepheline syenites, dark blue $=$ Chilwa carbonatites, pink $=$ Tambani

917 nepheline syenites, green $=$ Bull's Run nepheline syenites, light blue $=$ Bull's Run

918 carbonatites.

919

920 
Table 1. Rb-Sr, Sm-Nd and Lu-Hf isotopic and concentration data for alkaline rocks and carbonatites.

\begin{tabular}{|c|c|c|c|c|c|c|c|c|c|c|c|c|c|c|c|}
\hline \multirow{3}{*}{$\begin{array}{l}\text { Sample No. } \\
\text { Rock Type } \\
\text { T = Age (Ma) }\end{array}$} & \multicolumn{3}{|c|}{ Bull's Run, South Africa } & \multicolumn{6}{|c|}{ Tambani, Malawi } & \multicolumn{3}{|c|}{ Chilwa Island, Malawi } & \multicolumn{3}{|c|}{ Mongolowe, Malawi } \\
\hline & $\begin{array}{l}\text { BRM02-1 } \\
\text { nepheline }\end{array}$ & $\begin{array}{l}\text { BRM02-7 } \\
\text { sy gneiss }\end{array}$ & $\begin{array}{c}\text { BRM02-3 } \\
\text { carbonatite }\end{array}$ & $\begin{array}{c}\text { TH-2 } \\
\text { nephel }\end{array}$ & $\begin{array}{c}\mathrm{TH}-3 \\
\text { ine syenite }\end{array}$ & $\begin{array}{l}\text { TH-5 } \\
\text { gneiss }\end{array}$ & $\begin{array}{r}78 / 52 \\
\text { zirc }\end{array}$ & $\begin{array}{c}78 / 57 \\
\text { on megacry }\end{array}$ & $\begin{array}{l}78 / 62 \\
\text { /sts }\end{array}$ & $\mathrm{Cl}-1$ & $\begin{array}{c}\mathrm{Cl}-2 \\
\text { carbonatite }\end{array}$ & $\mathrm{Cl}-3$ & $\begin{array}{r}\text { MM03-30 } \\
\text { nephel }\end{array}$ & $\begin{array}{l}\text { MM03-35 } \\
\text { line syenite }\end{array}$ & $\begin{array}{l}\text { MMO3-45 } \\
\text { gneiss }\end{array}$ \\
\hline & 1134 & 1134 & 1134 & 726 & 726 & 726 & 726 & 726 & 726 & 130 & 130 & 130 & 130 & 130 & 130 \\
\hline $\mathrm{Rb}(\mathrm{ppm})$ & 105 & 128 & 69.5 & 42.2 & 42.8 & 36.5 & & & & 0.313 & 0.763 & 3.003 & 61.1 & 52.3 & 71.7 \\
\hline $\operatorname{Sr}(\mathrm{ppm})$ & 857 & 532 & 5759 & 839 & 609 & 847 & & & & 2917 & 4445 & 9020 & 596 & 337 & 210 \\
\hline${ }^{87} \mathrm{Rb} /{ }^{86} \mathrm{Sr}$ & 0.3546 & 0.6966 & 0.0349 & 0.1455 & 0.2033 & 0.1246 & & & & 0.0003 & 0.0005 & 0.0010 & 0.2965 & 0.4493 & 0.9891 \\
\hline $\begin{array}{l}{ }^{87} \mathrm{Sr} /{ }^{86} \mathrm{Sr} \\
\pm(2 \sigma)\end{array}$ & $\begin{array}{c}0.709098 \\
17\end{array}$ & $\begin{array}{c}0.709156 \\
12\end{array}$ & $\begin{array}{c}0.703406 \\
17\end{array}$ & $\begin{array}{c}0.704425 \\
15\end{array}$ & $\begin{array}{c}0.704961 \\
20\end{array}$ & $\begin{array}{c}0.704276 \\
11\end{array}$ & & & & $\begin{array}{c}0.703472 \\
13\end{array}$ & $\begin{array}{c}0.703469 \\
19\end{array}$ & $\begin{array}{c}0.703481 \\
20\end{array}$ & $\begin{array}{c}0.704312 \\
16\end{array}$ & $\begin{array}{c}0.704336 \\
19\end{array}$ & $\begin{array}{c}0.70509 \\
12\end{array}$ \\
\hline$I_{S r}, T$ & 0.703343 & 0.697854 & 0.703839 & 0.702917 & 0.702854 & 0.702984 & & & & 0.703471 & 0.703468 & 0.703479 & 0.703764 & 0.703507 & 0.703265 \\
\hline $\mathrm{I}_{\mathrm{Sr}}, 130 \mathrm{Ma}$ & 0.708443 & 0.707870 & 0.703342 & 0.704156 & 0.704585 & 0.704046 & & & & 0.703471 & 0.703468 & 0.703479 & 0.703764 & 0.703507 & 0.703265 \\
\hline Sm (ppm) & 14.04 & 2.54 & 24.04 & 3.29 & 5.09 & 2.78 & & & & 158.8 & 40.86 & 115.2 & 8.85 & 9.21 & 4.39 \\
\hline $\mathrm{Nd}(\mathrm{ppm})$ & 100.5 & 22.5 & 152.4 & 20.2 & 32.2 & 17.0 & & & & 1351 & 277 & 971 & 63.7 & 70.0 & 31.8 \\
\hline${ }^{147} \mathrm{Sm} /{ }^{144} \mathrm{Nd}$ & 0.08445 & 0.06824 & 0.09535 & 0.09846 & 0.09556 & 0.09886 & & & & 0.07106 & 0.08918 & 0.07173 & 0.08399 & 0.07954 & 0.08346 \\
\hline${ }^{143} \mathrm{Nd} / /^{144} \mathrm{Nd}$ & $\begin{array}{c}0.512001 \\
4\end{array}$ & 0.511913 & 0.511961 & 0.512367 & 0.512345 & 0.512355 & & & & 0.512696 & 0.512716 & 0.512693 & 0.512679 & 0.512674 & 0.512671 \\
\hline $\begin{array}{l} \pm(2 \sigma) \\
I_{N d}, T\end{array}$ & $\begin{array}{c}4 \\
0.511447\end{array}$ & $\begin{array}{c}10 \\
0.511465\end{array}$ & $\begin{array}{c}4 \\
0.511335\end{array}$ & $\begin{array}{c}4 \\
0.511898\end{array}$ & $\begin{array}{c}5 \\
0.511890\end{array}$ & $\begin{array}{c}5 \\
0.511884\end{array}$ & & & & $\begin{array}{c}5 \\
0.512636\end{array}$ & $\begin{array}{c}7 \\
0.512640\end{array}$ & $\begin{array}{c}5 \\
0.512632\end{array}$ & $\begin{array}{c}4 \\
0.512677\end{array}$ & $\begin{array}{c}6 \\
0.512606\end{array}$ & $\begin{array}{c}5 \\
0.512600\end{array}$ \\
\hline$\varepsilon_{\mathrm{Nd}}(T)^{1}$ & 3.89 & 4.52 & 1.52 & 3.84 & 3.68 & 3.57 & & & & 3.22 & 3.31 & 3.15 & 2.67 & 2.65 & 2.52 \\
\hline$\varepsilon_{\mathrm{Nd}}(130 \mathrm{Ma})^{1}$ & -10.57 & -12.01 & -11.53 & -3.66 & -4.04 & -3.90 & & & & 3.22 & 3.31 & 3.15 & 2.67 & 2.65 & 2.52 \\
\hline $\mathrm{T}_{\mathrm{DM}}(\mathrm{Ga})^{2}$ & 1.290 & 1.238 & 1.464 & 0.962 & 0.967 & 0.981 & & & & 0.416 & 0.453 & 0.421 & 0.479 & 0.468 & 0.486 \\
\hline Lu (ppm) & 0.326 & 0.049 & 1.132 & 0.070 & 0.122 & 0.062 & & & & 0.880 & 0.806 & 0.876 & 0.386 & 0.274 & 0.344 \\
\hline $\mathrm{Hf}(\mathrm{ppm})$ & 5.621 & 0.525 & 0.587 & 0.100 & 1.215 & 0.099 & & & & 4.624 & 0.388 & 0.957 & 4.656 & 3.434 & 7.653 \\
\hline${ }^{176} \mathrm{Lu} /{ }^{177} \mathrm{Hf}$ & 0.0082 & 0.0133 & 0.2726 & 0.0992 & 0.0143 & 0.0884 & & & & 0.0269 & 0.2941 & 0.1294 & 0.0118 & 0.0113 & 0.0064 \\
\hline $\begin{array}{l}{ }^{176} \mathrm{Hf} /{ }^{177} \mathrm{Hf} \\
\pm(2 \sigma)\end{array}$ & $\begin{array}{c}0.282175 \\
5\end{array}$ & $\begin{array}{c}0.282349 \\
18\end{array}$ & & $\begin{array}{c}0.282217 \\
32\end{array}$ & $\begin{array}{c}0.282443 \\
8\end{array}$ & $\begin{array}{c}0.282232 \\
40\end{array}$ & $\begin{array}{c}0.282466 \\
57\end{array}$ & $\begin{array}{c}0.282475 \\
57\end{array}$ & $\begin{array}{c}0.282454 \\
57\end{array}$ & & & & $\begin{array}{c}0.282791 \\
9\end{array}$ & $\begin{array}{c}0.28275 \\
8\end{array}$ & $\begin{array}{c}0.282741 \\
5\end{array}$ \\
\hline$\varepsilon_{\mathrm{Hf}}(\mathrm{T})^{1}$ & -2.24 & 0.05 & & -3.61 & 4.36 & -3.11 & 5.19 & 5.51 & 4.77 & & & & 2.50 & 1.09 & 1.21 \\
\hline$\varepsilon_{\mathrm{Hf}}(130 \mathrm{Ma})^{1}$ & -18.97 & -13.26 & & 22.54 & -3.15 & 18.79 & -7.97 & -7.66 & -8.40 & & & & 2.50 & 1.09 & 1.21 \\
\hline
\end{tabular}

${ }^{1}$ CHUR parameters: ${ }^{147} \mathrm{Sm} /{ }^{144} \mathrm{Nd}=0.1967,{ }^{143} \mathrm{Nd} /{ }^{144} \mathrm{Nd}=0.512638 ;{ }^{176} \mathrm{Lu} /{ }^{177} \mathrm{Hf}=0.0332,{ }^{176} \mathrm{Hf} /{ }^{177} \mathrm{Hf}=0.282772$

${ }^{2}$ Based on depleted mantle model of De Paolo et al. (1991): $\varepsilon_{\mathrm{Nd}, \mathrm{T}}=8.6-1.91 \mathrm{~T}$ 


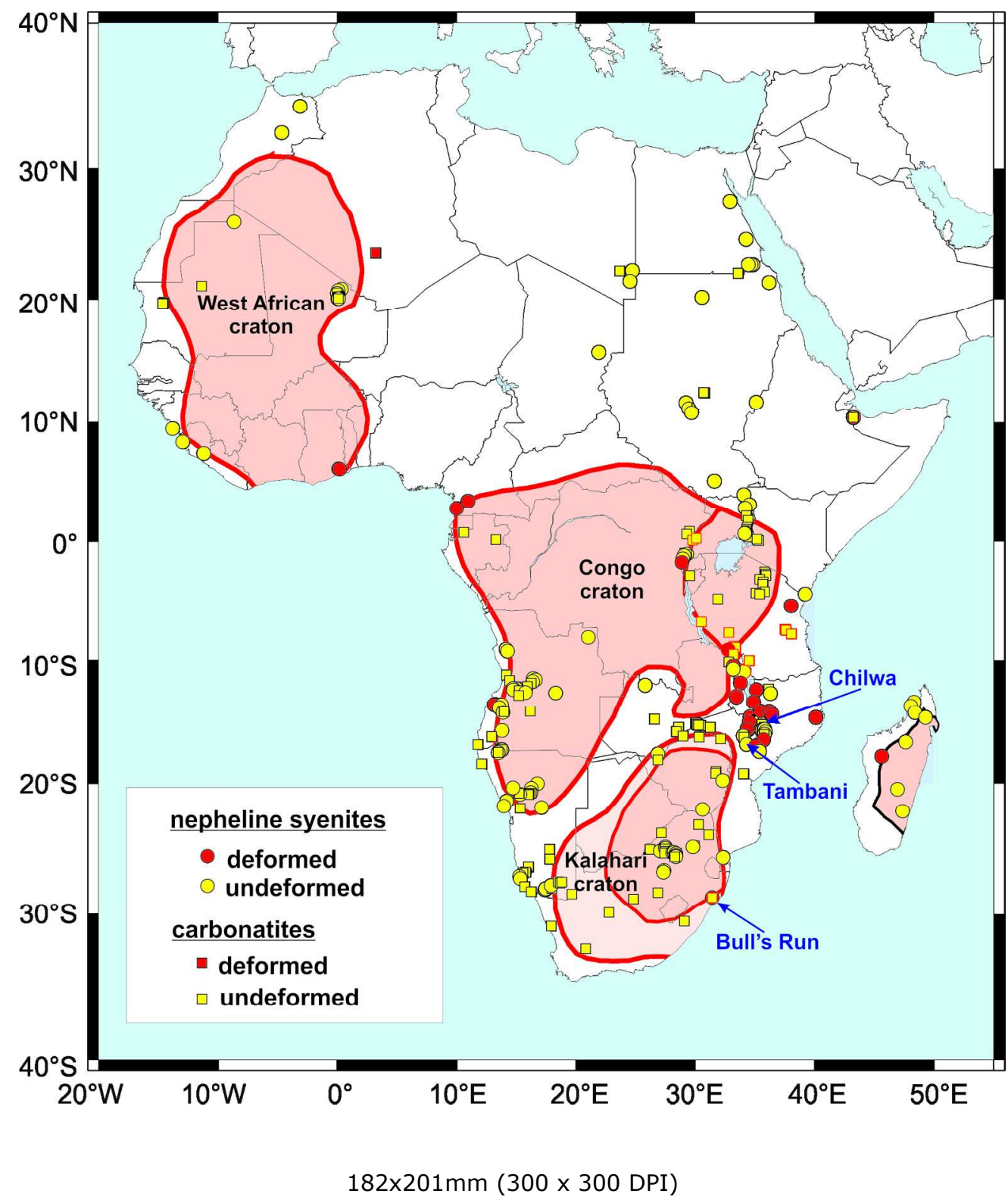




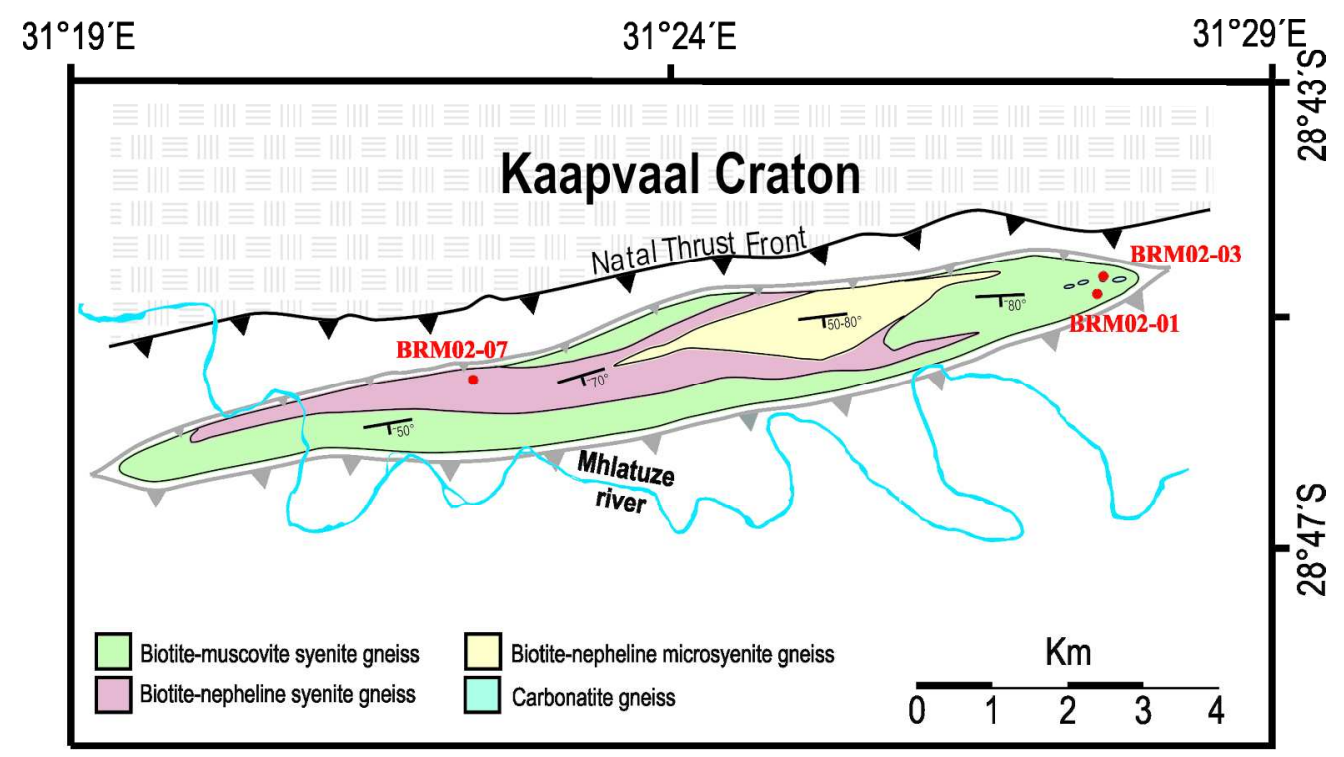

$196 \times 110 \mathrm{~mm}(300 \times 300$ DPI $)$ 


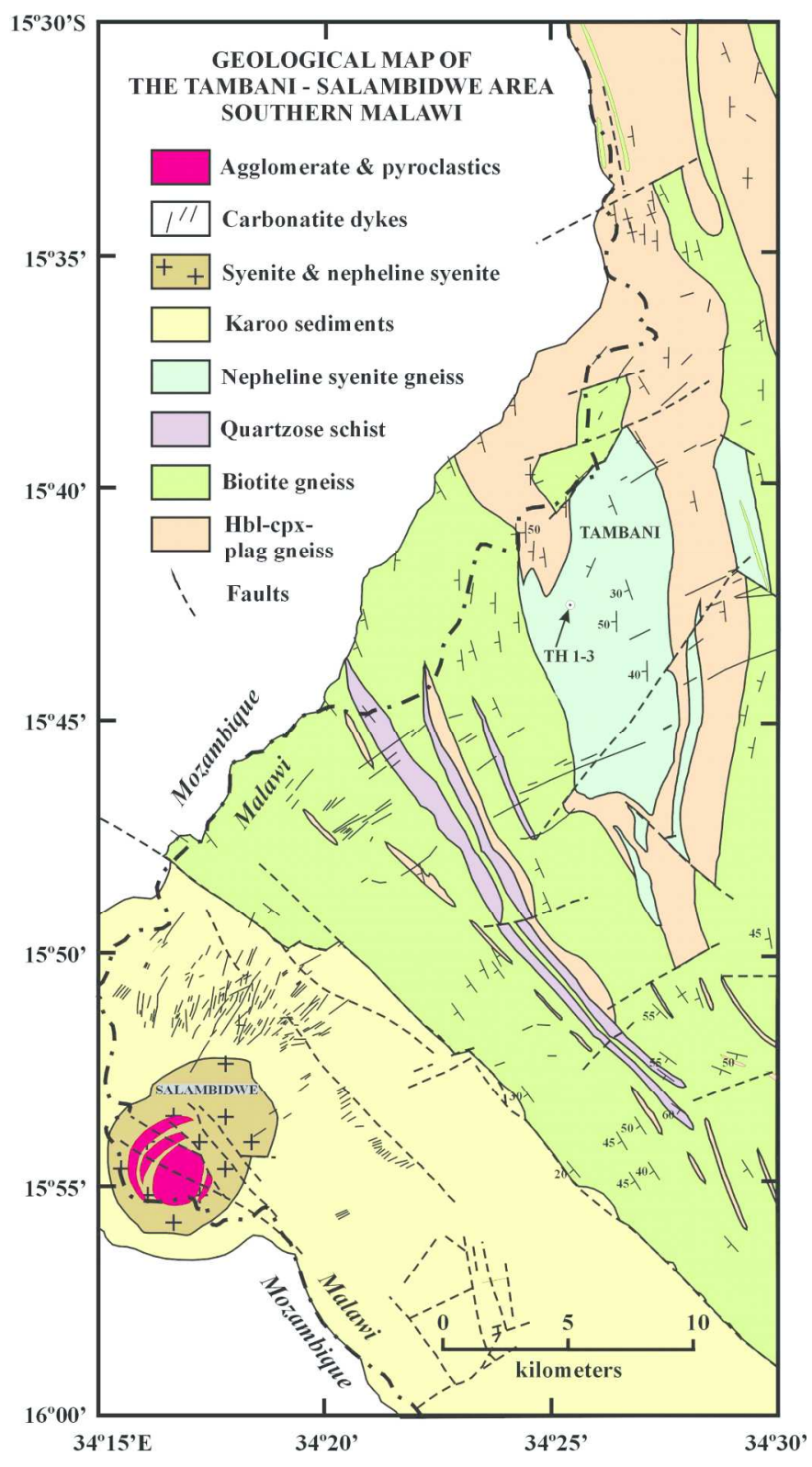

$157 \times 282 \mathrm{~mm}(300 \times 300$ DPI $)$ 


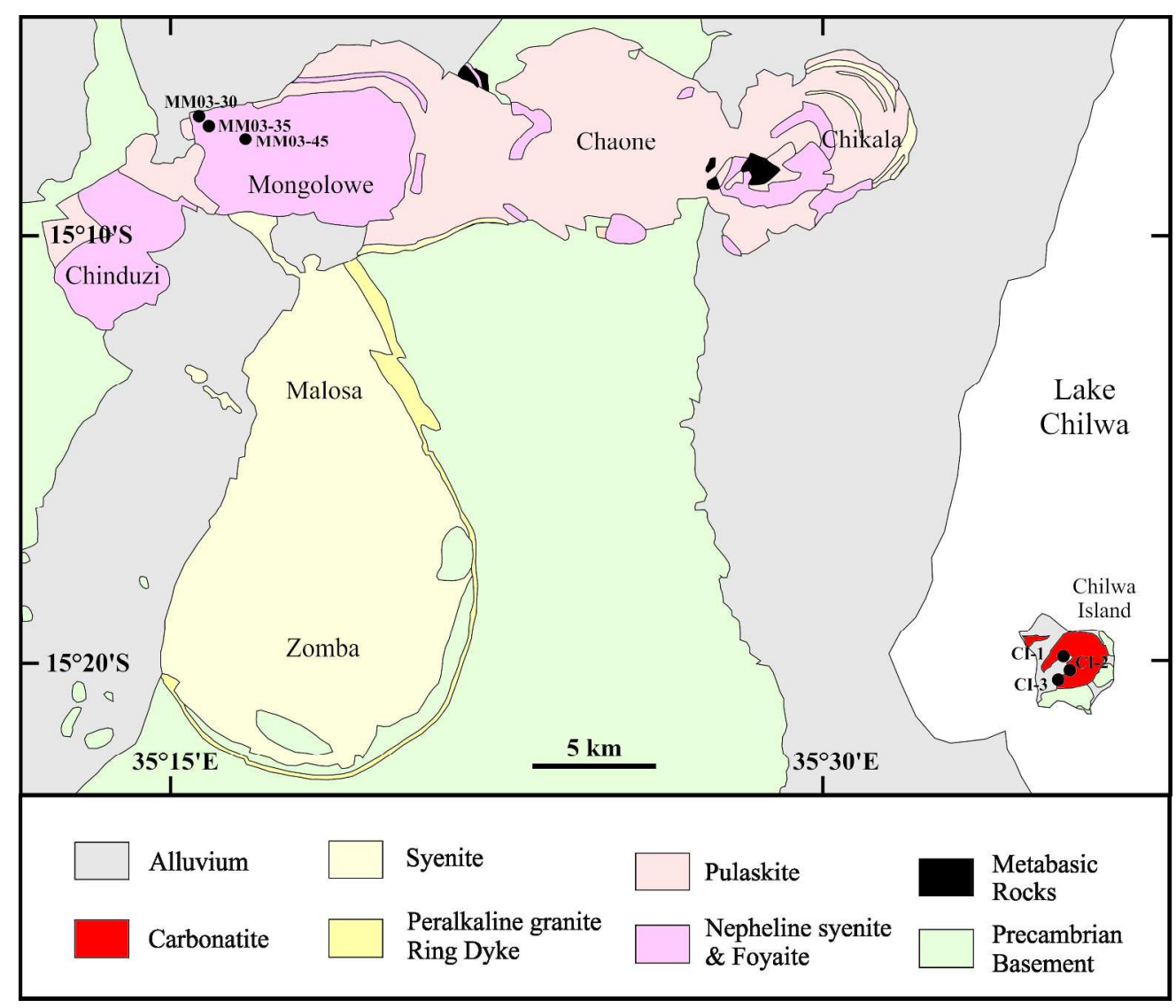

$236 \times 202 \mathrm{~mm}(300 \times 300$ DPI $)$ 


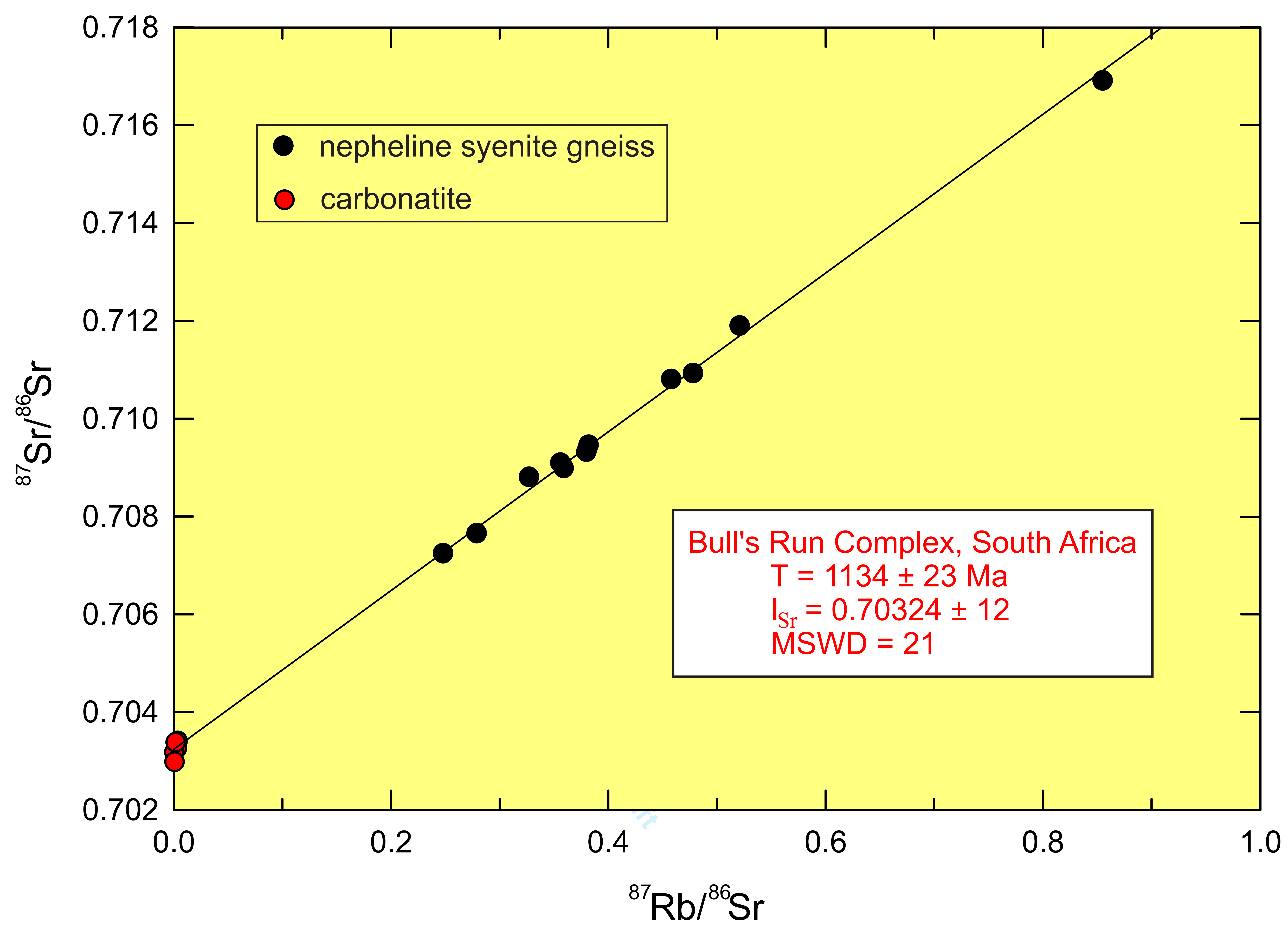




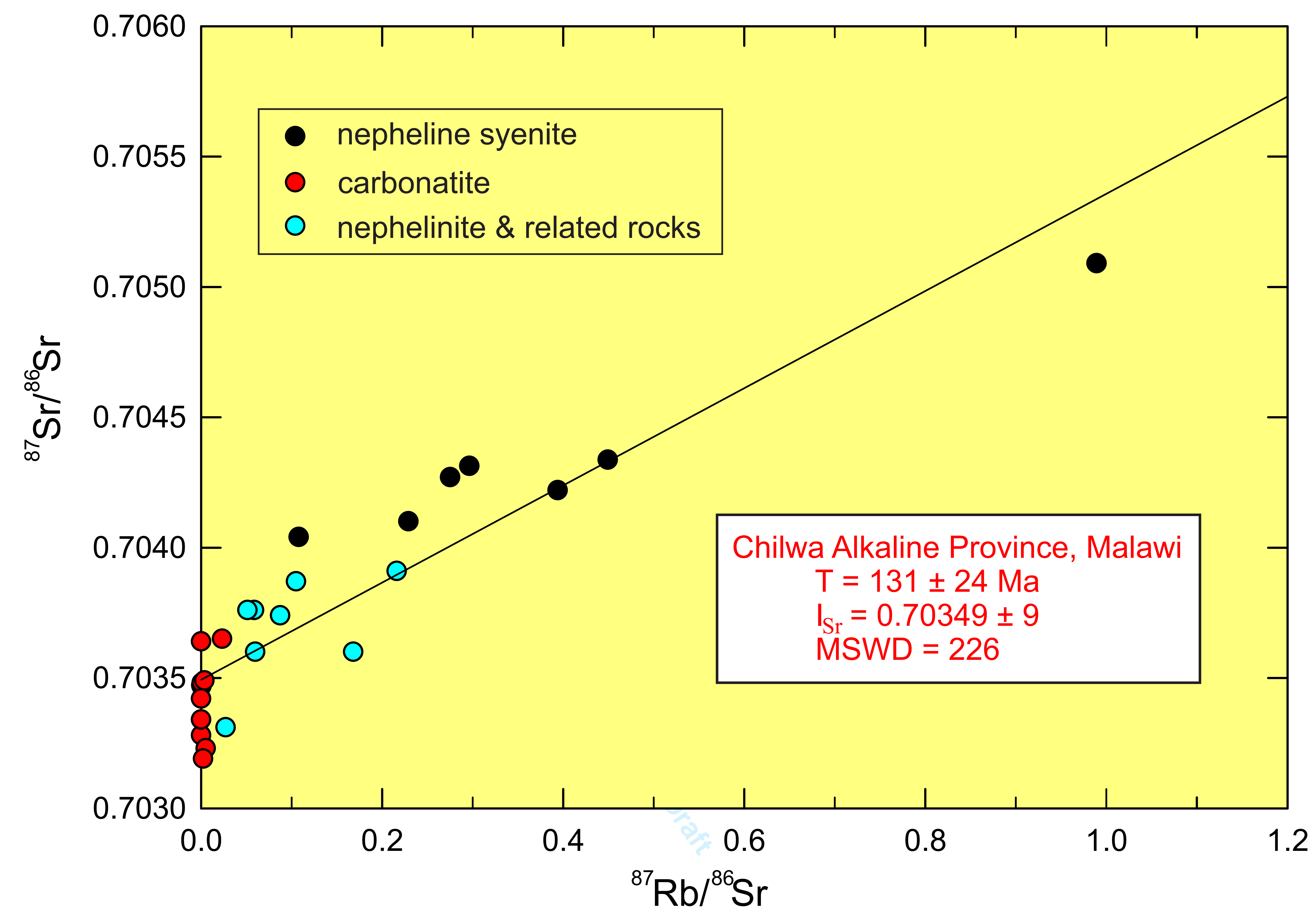



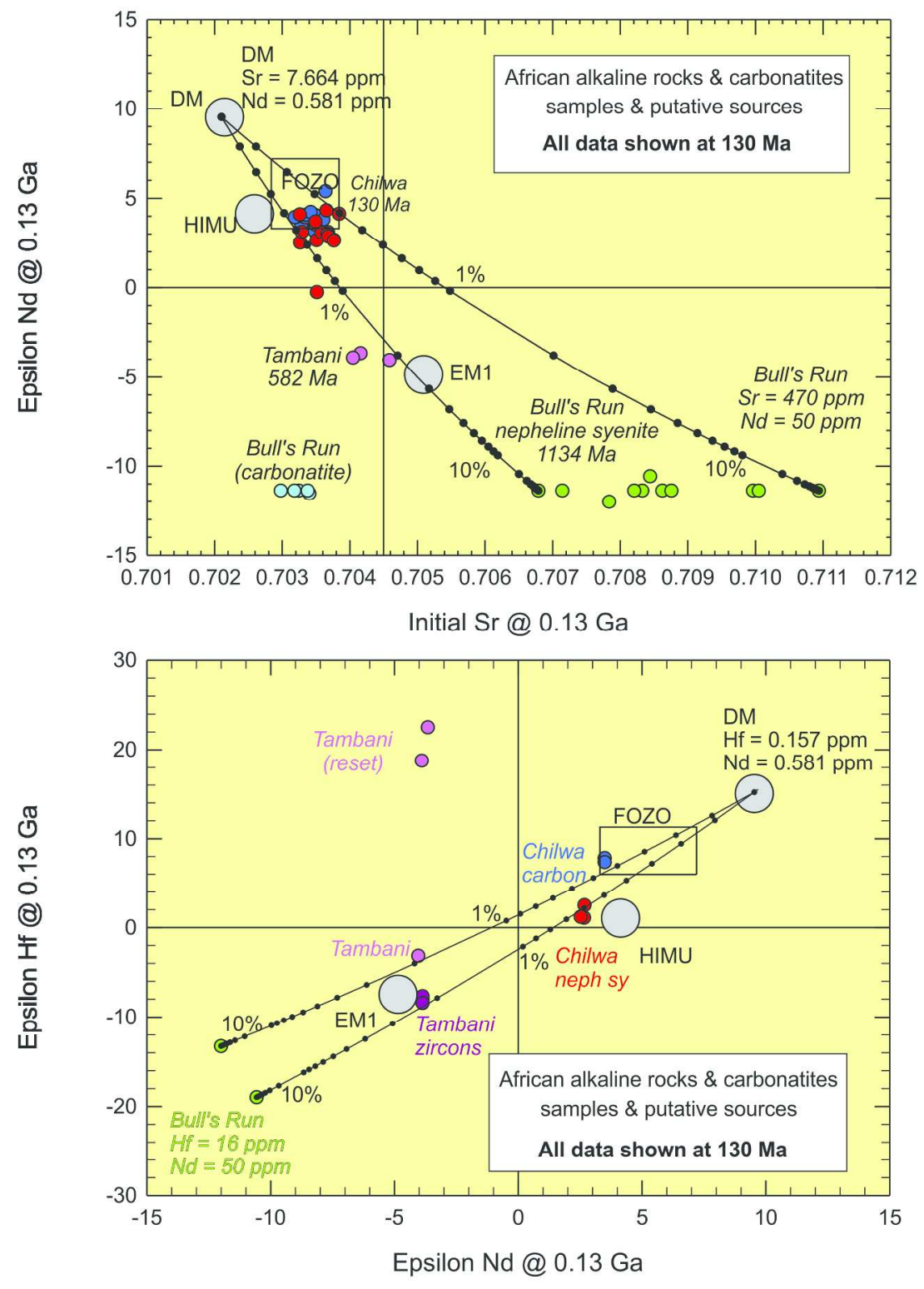

$194 \times 276 \mathrm{~mm}(300 \times 300$ DPI $)$ 